\title{
Assessment of Methanol Electro-Oxidation for Direct Methanol-Air Fuel Cells
}
S. D. Fritts
R. K. Sen

July 1988

Prepared for the U.S. Department of Energy under Contract DE-AC06-76RLO 1830

Pacific Northwest Laboratory Operated for the U.S. Department of Energy by Battelle Memorial Institute 


\title{
DISCLAIMER
}

This report was prepared as an account of work sponsored by an agency of the United States Government. Neither the United States Government nor any agency thereof, nor Battelle Memorial Institute, nor any or their employees, makes any warranty, expressed or implied, or assumes any legal liability or responsibility for the accuracy, completeness, or usefulness of any information, apparatus, product, or process disclosed, or represents that its use would not infringe privately owned rights. Reference herein to any specific commercial product, process, or service by trade name, trademark, manufacturer, or otherwise does not necessarily constitute or imply its endorsement, recommendation, or favoring by the United States Government or any agency thereof, or Battelle Memorial Institute. The views and opinions of authors expressed herein do not necessarily state or reflect those of the United States Government or any agency thereof, or Battelle Memorial Institute.

\author{
PACIFIC NORTHWEST LABORATORY \\ operated by \\ BATTELLE MEMORIAL INSTITUTE \\ for the \\ UNITED STATES DEPARTMENT OF ENERGY \\ under Contract DE-ACO6-76RLO 1830
}

\begin{tabular}{|c|c|}
\hline \multicolumn{2}{|c|}{ Printed in the United States of America } \\
\hline \multicolumn{2}{|c|}{$\begin{array}{l}\text { Available from } \\
\text { National Technical Information Service }\end{array}$} \\
\hline \multicolumn{2}{|c|}{$\begin{array}{c}\text { United States Department of Commerce } \\
\text { 5285 Port Royal Road } \\
\text { Springfield, Virginia } 22161\end{array}$} \\
\hline \multicolumn{2}{|c|}{$\begin{array}{l}\text { NTIS Price Codes } \\
\text { Microfiche A01 }\end{array}$} \\
\hline \multicolumn{2}{|c|}{ Printed Copy } \\
\hline Pages & $\begin{array}{l}\text { Price } \\
\text { Codes }\end{array}$ \\
\hline $001-025$ & $\mathrm{AD}_{2}$ \\
\hline $026-050$ & $\mathrm{AO} 3$ \\
\hline $051-075$ & $\mathrm{AO4}$ \\
\hline $076-100$ & $\mathrm{~A} 05$ \\
\hline $101-125$ & $A 06$ \\
\hline $126-150$ & $\mathrm{~A} 07$ \\
\hline $151-175$ & $A 0 B$ \\
\hline $176-200$ & $\mathrm{~A} 09$ \\
\hline $201-225$ & $A 010$ \\
\hline $226-250$ & A011 \\
\hline $251-275$ & $A 012$ \\
\hline $276-300$ & $\mathrm{~A} 013$ \\
\hline
\end{tabular}


PNL-6077

UC-95

\section{2}

ASSESSMENT OF METHANOL ELECTRO-OXIDATION

FOR DIRECT METHANOL-AIR FUEL CELLS

S. D. Fritts

R. K. Sen

Ju7y 1988

Prepared for the U.S. Department of Energy under Contract DE-AC06-76RLO 1830

Pacific Northwest Laboratory

Richland, Washington 99352 
$\because$ 


\section{SUMMARY}

Methanol-air fuel cells are attractive power sources for electric vehicles; they can be operated on domestic nonpetroleum fuels and are environmentally benign. In addition, fuel cells are inherently more efficient than conventional internal combustion engines because they are not limited by the Carnot cycle.

The Office of Energy Storage and Distribution of the U.S. Department of Energy (DOE) supports the development of a methanol-air fuel cell for transportation application. The approach used at Los ATamos National Laboratory converts the methanol fuel to a hydrogen-rich gas in a reformer, then operates the fuel cell on hydrogen and air. The reformer tends to be bulky (raising vehicle packaging problems), has a long startup period, and is not well suited for the transient operation required in a vehicle.

Methanol, however, can be oxidized electrochemically in the fuel cell. If this process can be conducted efficiently, a direct methanol-air fuel cell can be used, which does not require a reformer. The objective of this study is to assess the potential of developing a suitable catalyst for the direct electrochemical oxidation of methanol.

The primary conclusion of this study is that no acceptable catalysts exist that can efficiently oxidize methanol electrochemically and have the desired cost and lifetime for vehicle applications. However, recent progress in understanding the mechanism of methanol oxidation indicates that a predictive base can be developed to search for methanol oxidation catalysts and can be used to methodically develop improved catalysts. Such an approach is strongly recommended. The study also recommends that until further progress in developing high-performance catalysts is achieved, research in cell design and testing is not warranted. 


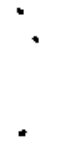

.

. 


\section{CONTENTS}

SUMMARY ................................

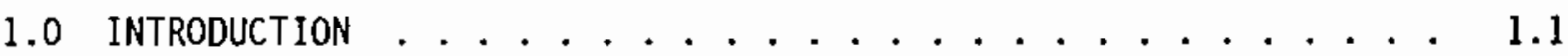

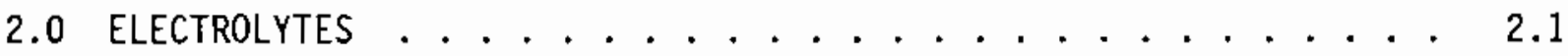

2.1 ACIDIC ELECTROLYTES . . . . . . . . . . . 2.1

2.2 ALKALINE ELECTROLYTES . . . . . . . . . . . 2.3

2.3 COMPARISON OF ELECTROLYTES . . . . . . . . . . . 2.5

3.0 MECHANISM OF METHANOL ElECTRO-OXIDATION ........... 3.1

3.1 ACIDIC ELECTROLYTES . . . . . . . . . . . . 3.1

3.2 ALKALINE ELECTROLYTES . . . . . . . . . . 3.3

4.0 CATALYSTS FOR METHANOL ELECTRO-OXIDATION .......... 4.1

4.1 ACIDIC ELECTROLYTES ................... 4.1

4.2 ALKALINE ElECTROLYTES . . . . . . . . . . . 4.7

5.0 PERFORMANCE TARGETS FOR METHANOL ELECTRO-OXIDATION
CATALYSTS . ...... 5.1

6.0 CONCLUSIONS AND RECOMMENDATIONS . . . . . . . . . 6.1

7.0 REFERENCES ............................ 7.1

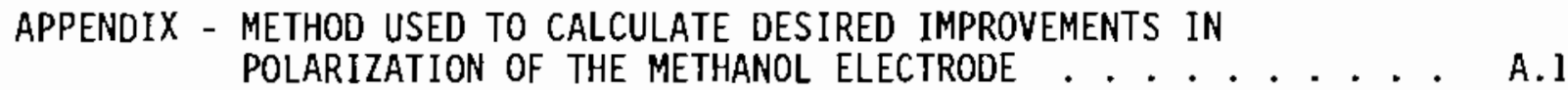




\section{FIGURES}

2.1 Dependence of Catalytic Activity of Pt Electrodeposit on Electrolyte Type and Concentration ........... 2.2

2.2 Performance of Pt Adams Catalyst for Methanol ElectroOxidation in $\mathrm{CF}_{3} \mathrm{SO}_{3} \mathrm{H} \cdot \mathrm{H}_{2} \mathrm{O} \ldots \ldots \ldots \ldots . \ldots . \ldots . \ldots$

2.3 Performance of Pt-Ru Adams Bimetallic Catalyst for Electro0xidation of Methanol in $25 \mathrm{wt} \% \mathrm{CF}_{3} \mathrm{SO}_{3} \mathrm{H}$ Solution ....... 2.4

2.4 Equilibrium Pressure of Water Vapor over $40 \%$ Equivalent Potassium Carbonate Solution ............. 2.6

4.1 Comparison of Catalyst Performance for the Direct 0xidation of

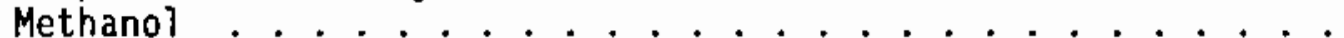

4.2 Direct Electrochemical 0xidation of Methanol on a Pt-Sn

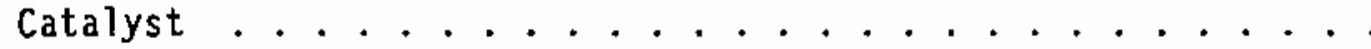

4.3 Current Versus Polarization Time Relations at $0.6 \mathrm{~V}$ on Pt-SPE and Bulk Pt in $1 \mathrm{M} \mathrm{CH}_{3} \mathrm{OH}+1 \mathrm{M} \mathrm{HClO}_{4} \ldots . . . . . .$.

4.4 Potential Versus Time Relations of a Methanol Depolarized Anode of Pt-Ru Cluster Catalyst Supported on Carbon Black for Zinc Electrowinning .................

4.5 The Influence of Activation Conditions on the Performance of Pt-Ru Catalysts Supported on Pyrographite-Coated Carbon-Fiber Paper; $3 \mathrm{M} \mathrm{H}_{2} \mathrm{SO}_{4}, 1 \mathrm{M} \mathrm{CH} \mathrm{CH}_{3} \mathrm{OH} 60^{\circ} \mathrm{C} \ldots \ldots . . . . . . . .6$

4.6 Re1ationship Between Intrinsic Activity and Pt Surface Area for Methanol Oxidation of Hydrogen-Activated Pt on Pyrographite-Coated Carbon-Fiber Paper ...........

4.7 Ratios Between the Current of Methanol 0xidation on the Binary Electrode $\mathrm{Pt}+\mathrm{X}$ (with $\mathrm{X}=\mathrm{Pb}, \mathrm{Bi}, \mathrm{Cd}, \mathrm{Tl}$ ) and the Current on $\mathrm{Pt}$, as a Function of the Electrode Potential in $0.1 \mathrm{M} \mathrm{NaOH}$, $0.1 \mathrm{M} \mathrm{CH}_{3} \mathrm{OH}$, at $25^{\circ} \mathrm{C}, 50 \mathrm{mV} / \mathrm{s} \ldots \ldots \ldots$

5.1 Comparison of the Calculated Methanol-Air Cell Voltage to the Target Cell Voltage in Phosphoric Acid Electrolyte at $200^{\circ} \mathrm{C} .$. 


\section{TABLE}

5.1 Results of Calculations Estimating the Polarization of the Anode of the Methanol-Air Cell for the Direct Methanol-Air System to be as Efficient as the Reformed Methanol-Air System . . . . . 5.3 


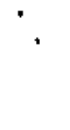




\subsection{INTRODUCTION}

Fuel cell-powered electric vehicles can be comparable in performance and range to internal combustion engine (ICE) vehicles. They can be operated on nonpetroleum fuels, reducing U.S. dependency on foreign energy sources. Fuel cells are environmentally benign, emitting little or no noise and generating only carbon dioxide and water as by-products. In addition, fuel cells are inherently more efficient than the conventional ICEs because they are not limited by the Carnot cycle.

The types of fuel cells that have been considered for transportation applications include those based on aqueous electrolytes [acidic, alkaline, and proton exchange membrane (PEM) electrolytes], molten carbonate electrolytes, and solid oxide electrolytes. The nonaqueous systems require hightemperature operation $\left[1000^{\circ} \mathrm{C}\right.$ for the solid-oxide, and $650^{\circ} \mathrm{C}$ for the molten carbonate (Huff and Murray 1982)]. Therma 1 management and safety can become serious issues with these systems, making them less suitable for electric vehicle (EV) applications. The aqueous fuel cells can be operated at approximately ambient temperatures.

Some of the fuels that can be used to power a fuel cell are petroleum derivatives such as naphtha, methanol derived from natural gas or coal, hydrogen, and liquid ammonia (National Materials Advisory Board 1983). The petroleum derivatives must be desulfurized prior to steam reforming, to produce a hydrogen-rich gas that can be oxidized in the cell anode. Hydrogen and liquid ammonia can be readily oxidized in the fuel cell, but the distribution, storage, and safety of these fuels are important concerns. Methanol does not require desulfurization and could be easily distributed through the existing distribution system for gasoline.

The Office of Energy Storage and Distribution of the U.S. Department of Energy (DOE) has therefore undertaken a program to develop an aqueous fuel cell for a general-purpose vehicle using methanol as a fuel. The program is presently being managed by the Los Alamos National Laboratory. This program focuses on reforming the methanol into a hydrogen-rich gas that is then oxidized in the fuel cell. 
Methanol can also be directly electro-oxidized at the anode of a fuel ce17. Direct methanol-air cells would have the advantage of being the simplest method to use methanol as a fuel because no reformers are required (Landsman and Luczak 1981). The reformers tend to be bulky; consequently, locating the fuel cell system under the hood of the vehicle is a problem. The presence of a reformer substantially reduces the specific power of the system because of its additional weight. Also, reformers are usually designed for steady-state operation; high performance under transient load conditions is questionable.

Another advantage to direct methanol electro-oxidation is that the fuel is always dissolved in the electrolyte, allowing faster startup times because the electrodes are always at the correct potentials, even when the system is inactive (Fedele and Donley 1980).

The purpose of this study is to determine whether direct methanol-air fuel cells are feasible and, if so, to recommend the direction of research and development priorities. This report will focus on the methanol half-cell because the air electrode research under way for other fuel cells will be applicable to the direct methanol-air system. 


\subsection{ELECTROLYTES}

The electrolyte used to support the electro-oxidation of methanol is a critical factor in determining the type of catalyst to be used and the temperature of fuel cell operation. Requirements for the electrolyte are stated by Cairns and MacDonald (1964):

1. The fuel cell performance should not decrease over several hours of operation.

2. The electrolyte must support complete oxidation of the methanol.

3. Spontaneous reaction with the fuels or oxidation products should not occur.

4. The electrolyte must be $\mathrm{CO}_{2}$ rejecting.

5. There must be low solubility of the fuel in the electrolyte to prevent diffusion of the fuel to the cathode.

6. The electrolyte should possess sufficient conductance.

7. The electrolyte should not react with other cell components.

Methanol can be oxidized electrochemically in either acidic or alkaline electrolytes, even though difficulties in meeting the above criteria are associated with each.

\subsection{ACIDIC ELECTROLYTES}

The major advantage of acidic electrolytes is their ability to reject $\mathrm{CO}_{2}$. The major disadvantage is the lack of suitable catalysts and catalyst support. Most acid radicals adsorb on the catalyst surface, with a detrimental effect on the catalytic activity. Although perchloric acid has minimal poisoning effects, it would probably not be used in a commercial system for safety reasons (Andrew et a7. 1977). The common acids that can be used in direct methanol fuel cells are sulfuric acid and phosphoric acid.

The effects of sulfuric acid and phosphoric acid concentration on the activity of platinum (Pt) catalysts are shown in Figure 2.1. The decreases 


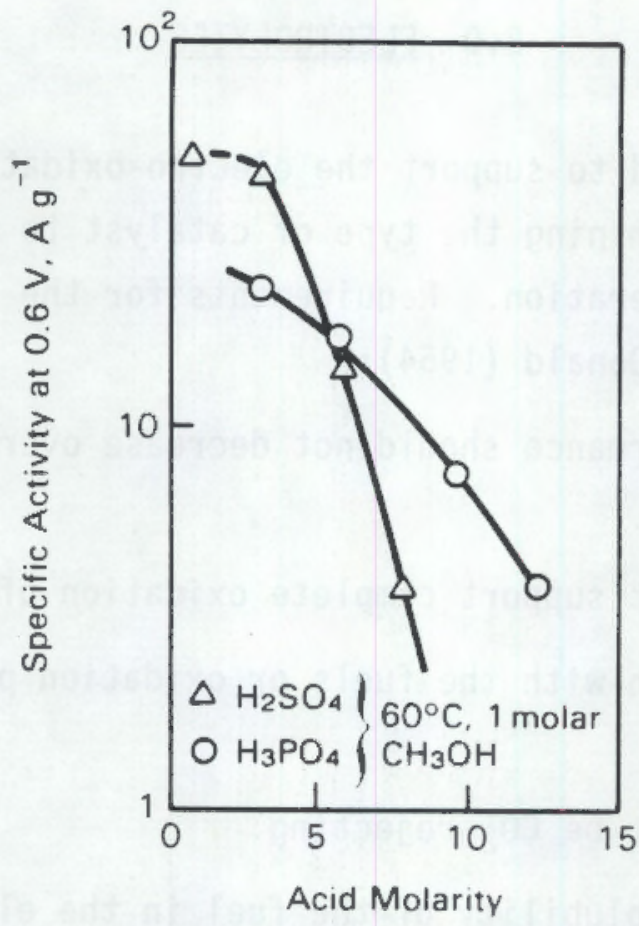

FIGURE 2.1. Dependence of Catalytic Activity of Pt Electrodeposit on Electrolyte Type and Concentration (McNicol 1984)

in the activity with increasing acid concentration are due to decreases in the water activity and to increases in the amount of undissociated acid. According to Andrew et al. (1977) and McNicol (1984), undissociated acid adsorbs on the catalyst surface, blocking the adsorption sites required for electro-oxidation of methanol.

The rate of $\mathrm{CH}_{3} \mathrm{OH}$ oxidation in phosphoric acid is lower than that in sulfuric acid at low concentrations because of the low dissociation of phosphoric acid (Andrew et al. 1977). Also, sulfuric acid is much more conductive than phosphoric acid (Andrew et al. 1977).

Phosphoric acid is a better electrolyte choice for high-concentration or higher-temperature operation; sulfuric acid has a water-balance problem at temperatures greater than $60^{\circ} \mathrm{C}$ (Andrew et al. 1977; McNicol 1981, 1984). At temperatures greater than $90^{\circ} \mathrm{C}$, with gaseous methanol fuel, catalytic activities of 16 molar (M) $\mathrm{H}_{3} \mathrm{PO}_{4}$ electrolyte are comparable to performance in $3 \mathrm{M}$ $\mathrm{H}_{2} \mathrm{SO}_{4}$ (Andrew et al. 1977). 
Trifluoromethane-sulfonic acid (TFMSA) electrolytes have been evaluated for electro-oxidation of methanol (Hughes et al. 1977) because TFMSA is one of the strongest protonic acids and should be resistant to thermal decomposition and hydrolysis. The acid anion is a very weak complexing agent and should have very little poisoning effect on catalytic activity (Hughes et al. 1977). However, the catalytic activity of Pt in TFMSA monohydrate was found to be an order of magnitude less than for $3 \mathrm{M}$ sulfuric acid, as shown in Figure 2.2. Although dilute solutions, 10 to $50 \%$ TFMSA, were found to exhibit greater activity than the monohydrate, the activity is comparable to that of $3 \mathrm{M}$ sulfuric acid. The performance of a $\mathrm{Pt}-\mathrm{Ru} / \mathrm{C}$ electrode in $25 \%$ TFMSA is shown in Figure 2.3. Above $80^{\circ} \mathrm{C}$, the catalysts were poisoned by sulfur species formed by the decomposition of TFMSA.

Based on these studies and on the higher cost of TFMSA, sulfuric acid is the superior acidic electrolyte for use in direct methanol fuel cells. The cell should be operated with sulfuric acid concentrations less than $3 \mathrm{M}$ and below $60^{\circ} \mathrm{C}$.

\subsection{ALKALINE ELECTROLYTES}

Alkal ine electrolytes, such as $\mathrm{KOH}$, have also been considered, but oxidation of methanol in alkaline electrolytes forms carbonates that lower the electrolyte conductivity and reduce the current density.

Buffered electrolytes have been studied for invariance in methanol fuel cells. When the cell was operated at temperatures close to the boiling point of the electrolyte, both concentrated $\mathrm{Cs}_{2} \mathrm{CO}_{3}$ and $\mathrm{Rb}_{2} \mathrm{CO}_{3}$ solutions were found to meet all the criteria listed above for an electrolyte (Cairns and MacDonald 1964; Cairns and Bartosik 1964; Rupich, Galligan and Brummer 1984). Both solutions are $\mathrm{CO}_{2}$ rejecting above $100^{\circ} \mathrm{C}$. Also, the $\mathrm{Cs}_{2} \mathrm{CO}_{3}, \mathrm{CsHCO}_{3}$, $\mathrm{Rb}_{2} \mathrm{CO}_{3}$, and $\mathrm{RbHCO}_{3}$ are very soluble in water, even at temperatures as low as $15^{\circ} \mathrm{C}$, for concentrations suitable for cell operation (Cairns and MacDonald 1964; Cairns and Bartosik 1964). Although $\mathrm{Cs}_{2} \mathrm{CO}_{3}$ or $\mathrm{Rb}_{2} \mathrm{CO}_{3}$ are ideal electrolytes, their cost and the lack of domestic reserves (Petkof 1975) make them unlikely candidates for general-purpose electric vehicles. 


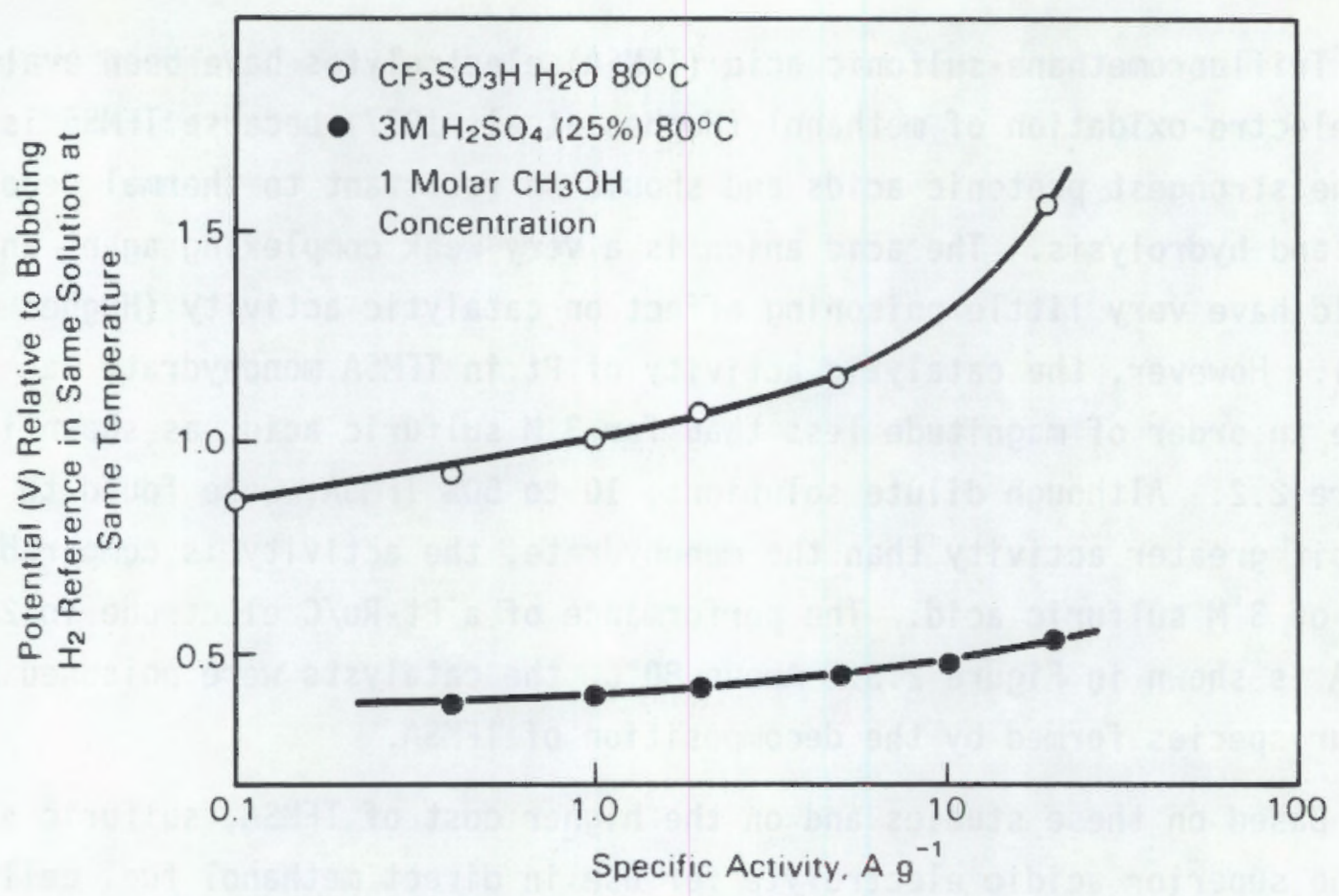

FIGURE 2.2. Performance of Pt Adams Catalyst for Methanol Electro-0xidation in $\mathrm{CF}_{3} \mathrm{SO}_{3} \mathrm{H}$. $\mathrm{H}_{2} \mathrm{O}$ (McNicol 1984)

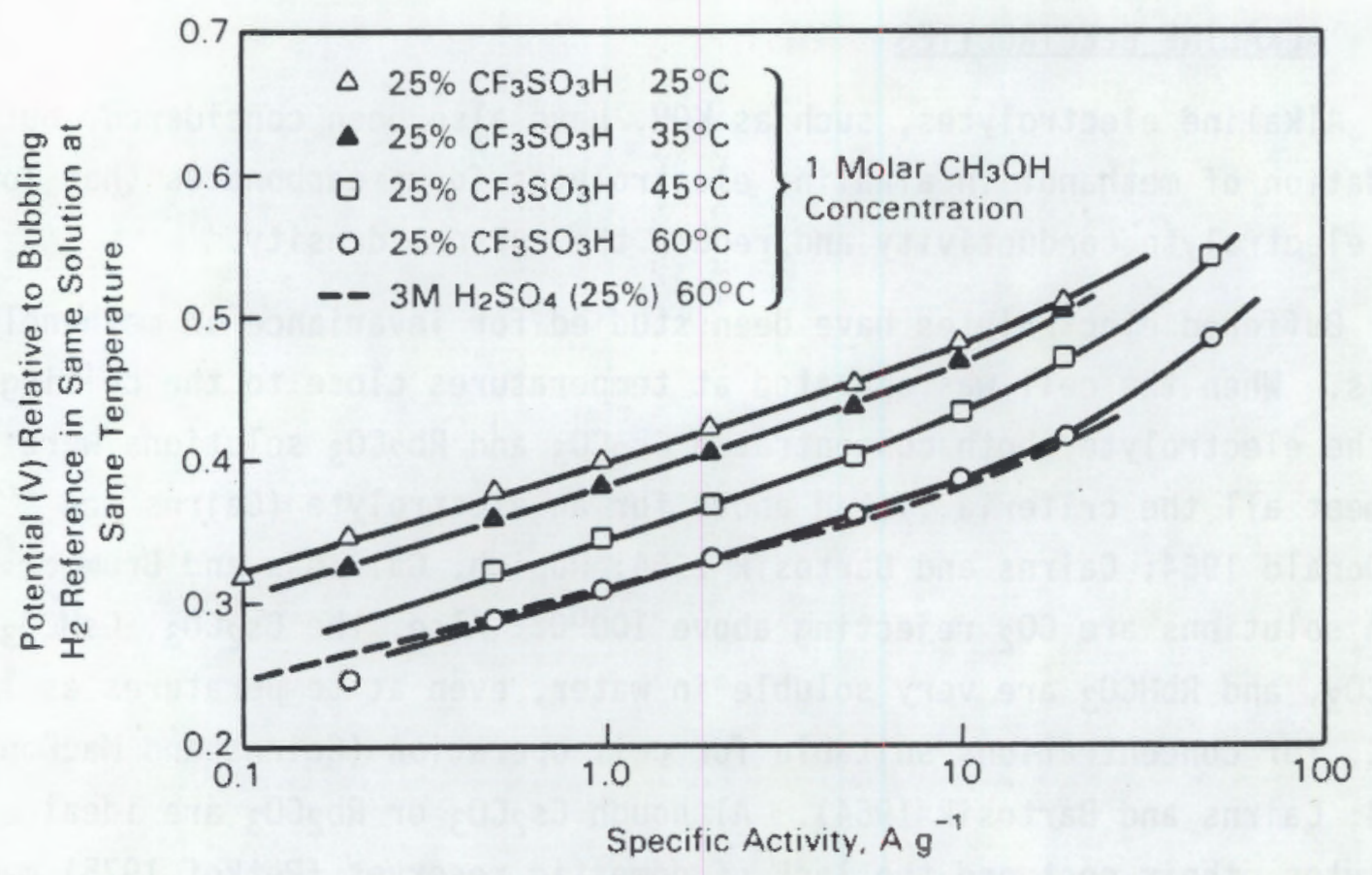

FIGURE 2.3. Performance of Pt-Ru Adams Bimetallic Catalyst for Electro-Oxidation of Methanol in 25 wt $\% \mathrm{CF}_{3} \mathrm{SO}_{3} \mathrm{H}$ Solution (MCNicol 1984) 
Buffered solutions of $\mathrm{K}_{2} \mathrm{CO}_{3}$ have limited solubilities below $100^{\circ} \mathrm{C}$ and atmospheric pressure; however, the solubilities of both potassium carbonate and potassium bicarbonate are reasonable for use as an electrolyte with cell operation $100^{\circ} \mathrm{C}$ and $200^{\circ} \mathrm{C}$, and with water vapor pressures greater than one atmosphere (Rupich, Galligan and Brummer 1984). Even under these conditions, the composition of the electrolyte must be controlled to prevent precipitation of the electrolyte. The composition of the $\mathrm{K}_{2} \mathrm{CO}_{3} / \mathrm{KHCO}_{3} / \mathrm{CO}_{2}$ system is determined by the reaction

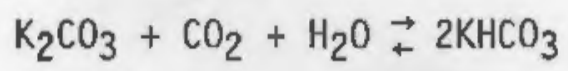

At about $50 \%$ conversion of $\mathrm{K}_{2} \mathrm{CO}_{3}$ to $\mathrm{KHCO}_{3}$, a large decrease occurs in the equilibrium water vapor pressure above the solution; therefore, small changes in the pressure of either the water or carbon dioxide can result in large changes in the electrolyte composition (Figure 2.4), which could cause precipitation. Therefore, the electrolyte should be maintained with a potassium carbonate conversion either well below or well above $50 \%$.

\subsection{COMPARISON OF ELECTROLYTES}

Although the buffered cesium and rubidium carbonates and bicarbonates are invariant electrolytes, their catalytic activities are not significantly higher than with a sulfuric acid electrolyte (McNicol 1984).

Sulfuric acid electrolytes, at concentrations less than three molar and at temperatures less than $60^{\circ} \mathrm{C}$, appear to be the best electrolyte for fuel cell applications. However, very concentrated phosphoric acid electrolytes with operation above $90^{\circ} \mathrm{C}$ seem promising and have been extensively researched in the development of the hydrogen-air fuel cell.

EIC Laboratories' results with buffered solutions of $\mathrm{K}_{2} \mathrm{CO}_{3}$ are positive (Rupich, Galligan and Brummer 1984), but further characterization of the electrolyte and the behavior of catalysts in this electrolyte are needed before judging its feasibility. 


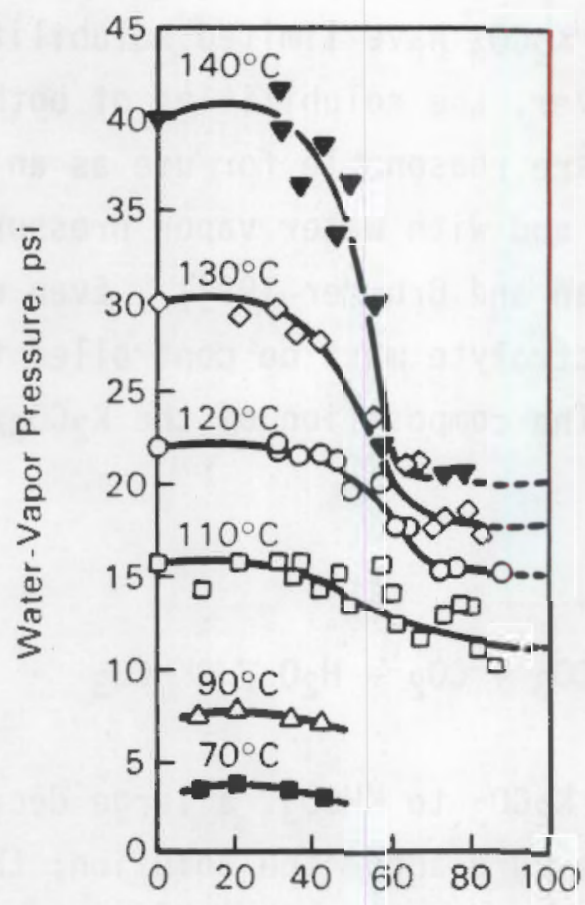

Percent of $\mathrm{K}_{2} \mathrm{CO}_{3}$ Converted to $\mathrm{KHCO}_{3}$

FIGURE 2.4. Equilibrium Pressure of Water Vapor over $40 \%$ Equivalent Potassium Carbonate Solution 


\subsection{MECHANISM OF METHANDL ELECTRO-OXIDATION}

A considerable amount of empirical research to find catalysts for methanol oxidation in acidic or alkaline media has had very little success. Some of the catalysts studied show very high initial activities that drop almost instantly and then decrease monotonically with time, especially in acidic media. Much of this research was conducted in the late 1960s and early 1970s (Cathro 1967; Janssen and Moolhuysen 1976a, 1976b; McNicol, Short and Chapman 1976; Watanabe and Motoo 1975).

The preferred approach would be to understand the mechanism of the reaction in both acidic and alkaline media and to develop a predictive base for a methodical search for promising catalysts for methanol oxidation. The following sections survey state-of-the-art mechanistic knowledge of methanol oxidation in acidic and alkaline electrolytes.

\subsection{ACIDIC ELECTROLYTES}

The mechanism of the methanol electro-oxidation reaction is speculative in an acidic electrolyte; however, two theories prevail. In one scheme, an adsorbed residue of methanol reacts with an adsorbed oxygen species to produce $\mathrm{CO}_{2}$. Using the approximate empirical formula of the adsorbed residue, $\mathrm{COH}$, the mechanism at the Pt electrode is as follows (Landsman and Luczak 1981; McNicol 1978, 1984):

$$
\begin{aligned}
& 3 \mathrm{Pt}+\mathrm{CH}_{3} \mathrm{OH} \rightarrow \mathrm{Pt}_{3} \mathrm{COH}+3 \mathrm{H}^{+}+3 \mathrm{e} \\
& 3 \mathrm{Pt}+3 \mathrm{H}_{2} \mathrm{O} \rightarrow 3 \mathrm{PtOH}+3 \mathrm{H}^{+}+3 \mathrm{e} \\
& \mathrm{Pt}_{3} \mathrm{COH}+\mathrm{PtOH} \rightarrow \mathrm{Pt}_{2} \mathrm{CO}+\mathrm{H}_{2} \mathrm{O}+2 \mathrm{Pt} \\
& \mathrm{Pt}_{2} \mathrm{CO}+\mathrm{PtOH} \rightarrow \mathrm{PtCOOH}+2 \mathrm{Pt} \\
& \mathrm{PtCOOH}+\mathrm{PtOH} \rightarrow \mathrm{CO}_{2}+\mathrm{H}_{2} \mathrm{O}+2 \mathrm{Pt}
\end{aligned}
$$

The first two steps of this mechanism are supported by cyclic voltammetric studies of the adsorbed species and potential-step measurements 
(Hughes and Miles 1983; Hampson, Willars and McNicol 1979). The remainder of the mechanism is speculative, based on indirect data.

The alternative scheme used to describe the electro-oxidation of methanol in an acidic medium postulates that two parallel mechanisms are involved. One produces formaldehyde, formic acid by-products and $\mathrm{CO}_{2}$ ' and the second produces a residue that is believed to be removed in a manner similar to that described above. This mechanism is (Breiter 1967a, 1967b; McNicol 1978):

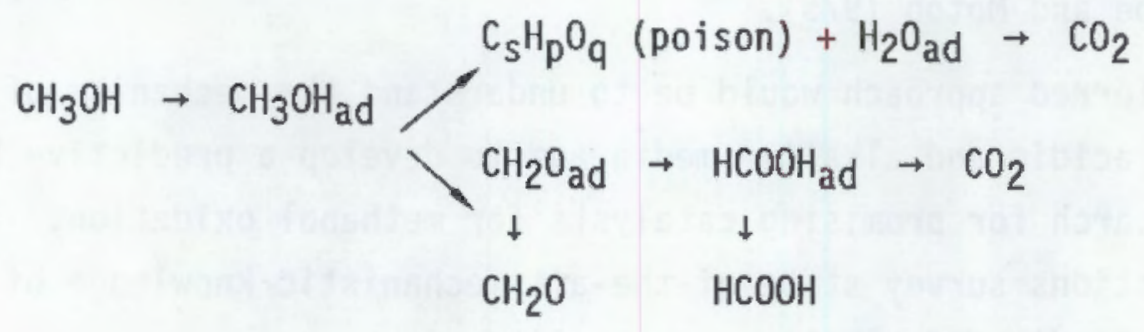

In this mechanism, the main reaction goes via formaldehyde and formic acid to $\mathrm{CO}_{2}$. The poison, $\mathrm{C}_{5} \mathrm{H}_{\mathrm{p}} \mathrm{O}_{\mathrm{q}}$, could be $\mathrm{CO}, \mathrm{H}_{2} \mathrm{CO}_{2}, \mathrm{C}_{2} \mathrm{O}_{2}$, and $\mathrm{H}_{2} \mathrm{C}_{2} \mathrm{O}_{3}$ (Breiter 1967a, 1967b) and is removed by adsorbed $\mathrm{H}_{2} \mathrm{O}$ or $\mathrm{OH}$. The intermediates of the reaction were studied using charging curves and gas chromatography. The intermediates of methanol electro-oxidation are similar to those for electro-oxidation of formic acid and formaldehyde in sulfuric acid solutions (Breiter 1967a, 1967b).

The initial rapid decrease of the current in both mechanisms is attributed to residue buildup on the surface, blocking the catalyst sites. The initial currents decrease by as much as a factor of $10^{5}$ during the first five minutes of operation (MCNicol 1981), indicating essentially that a significant portion of the catalytic sites is blocked. Both mechanisms postulate that further oxidation of the residue requires adsorbed water on adjacent catalytic sites. At the operating potentials of the methanol oxidation reaction, approximately 0.4 to $0.5 \mathrm{~V}$ versus normal hydrogen electrode (NHE), very little adsorption of water takes place on Pt. Water adsorption on Pt occurs only at about $0.8 \mathrm{~V}$ versus NHE at $50^{\circ} \mathrm{C}$ (Brookhaven National Laboratory 1979). Thus, Pt does not appear to be an ideal catalyst for 
methanol electro-oxidation. The best catalysts for this reaction must have the ability to adsorb water at potentials close to the operating potential for methanol oxidation.

Alloys of Pt are more active than Pt for electro-oxidation of methanol. The mechanism of methanol electro-oxidation on the platinum-ruthenium (Pt-Ru) catalyst was given by Watanabe and Motoo (1975):

$$
\begin{aligned}
& \mathrm{CH}_{3} \mathrm{OH}+3 \mathrm{Pt} \rightarrow \mathrm{HCO}-\mathrm{Pt}+3 \mathrm{H}-\mathrm{Pt} \\
& 3 \mathrm{H}-\mathrm{Pt} \rightarrow 3 \mathrm{Pt}+3 \mathrm{H}^{+}+3 \mathrm{e} \\
& \mathrm{H}_{2} \mathrm{O}+\mathrm{Pt}-\mathrm{Ru} \rightarrow \mathrm{HO}-\mathrm{Pt}-\mathrm{Ru}+\mathrm{H}^{+}+\mathrm{e} \\
& \mathrm{HCO}-\mathrm{Pt}+\mathrm{HO}-\mathrm{Pt}-\mathrm{Ru} \rightarrow \mathrm{Pt}+\mathrm{Pt}-\mathrm{Ru}+\mathrm{CO}_{2}+2 \mathrm{H}^{+}+2 \mathrm{e}
\end{aligned}
$$

Through cyclic voltammetry studies, it was shown that the Ru adsorbs the $\mathrm{OH}$ radicals in equation (3.10) at a more negative potential (from $0.35 \mathrm{~V}$ ) than Pt does (Watanabe and Motoo 1975). Because no adsorbed oxygen was found on the Ru sites, it has been postulated that reaction (3.11) occurs instantly after (3.10); therefore, the reaction rate for electro-oxidation of methanol is assumed to be proportional to the number of Ru sites located at the nearest neighbor of Pt sites having adsorbed $\mathrm{COH}$.

The mechanism for methanol oxidation on the Pt-Ru catalyst demonstrates that a good catalyst must have the ability to simultaneously adsorb methanol and water at potentials close to the potential of methanol oxidation.

\subsection{ALKALINE ELECTROLYTES}

Many catalysts can be used for methanol oxidation in an alkaline electrolyte (Fedele and Donley 1980), but maintaining an invariant electrolyte is difficult. In an alkaline electrolyte ( $\mathrm{KOH}$ or $\mathrm{NaOH})$, Beden et al. (1982) have postulated the following mechanism:

$$
\begin{aligned}
& \mathrm{Pt}+\mathrm{OH}^{-} \rightarrow \mathrm{Pt}-\mathrm{OH}+\mathrm{e} \\
& \mathrm{Pt}+\mathrm{CH}_{3} \mathrm{OH} \rightarrow \mathrm{Pt}-\left(\mathrm{CH}_{3} \mathrm{OH}\right) \\
& \mathrm{Pt}-\left(\mathrm{CH}_{3} \mathrm{OH}\right)+\mathrm{Pt}-\mathrm{OH} \rightarrow \mathrm{Pt}-\mathrm{CH}_{3} \mathrm{O}+\mathrm{Pt}+\mathrm{H}_{2} \mathrm{O} \\
& \mathrm{Pt}-\mathrm{CH}_{3} \mathrm{O}+\mathrm{Pt}-\mathrm{OH} \rightarrow \mathrm{Pt}-\mathrm{CH}_{2} \mathrm{O}+\mathrm{Pt}+\mathrm{H}_{2} \mathrm{O}
\end{aligned}
$$




$$
\begin{aligned}
& \mathrm{Pt}-\mathrm{CH}_{2} \mathrm{O}+\mathrm{Pt}-\mathrm{OH} \rightarrow \mathrm{Pt}-\mathrm{CHO}+\mathrm{Pt}+\mathrm{H}_{2} \mathrm{O} \\
& \mathrm{Pt}-\mathrm{CHO}+\mathrm{Pt}-\mathrm{OH} \rightarrow \mathrm{Pt}-\mathrm{CO}+\mathrm{Pt}+\mathrm{H}_{2} \mathrm{O} \\
& \mathrm{Pt}-\mathrm{CO}+\mathrm{Pt}-\mathrm{OH} \rightarrow \mathrm{Pt}-\mathrm{COOH}+\mathrm{Pt} \\
& \mathrm{Pt}-\mathrm{COOH}+\mathrm{OH}^{-} \rightarrow \mathrm{Pt}-\mathrm{OH}+\mathrm{HCOO}^{-} \\
& \mathrm{Pt}-\mathrm{COOH}+\mathrm{Pt}-\mathrm{OH}+2 \mathrm{OH}^{-} \rightarrow 2 \mathrm{Pt}+\mathrm{CO}_{3}{ }^{2-}+2 \mathrm{H}_{2} \mathrm{O}
\end{aligned}
$$

Reaction (3.19) or (3.20) will give the final product in the solution, either formate or carbonate ions, depending on the experimental conditions. The first two steps of this mechanism, (3.12) and (3.13), are based on cyclic voltammetry studies, and the remainder of the mechanism has been postulated on the basis of a possible adsorbed species $(-\mathrm{CO})$ that can accommodate the geometrical shape of the reacting species.

Based on this mechanism, as in acidic electrolytes, a catalyst for direct methanol oxidation must be able to simultaneously adsorb methanol and hydroxide ions at similar potentials, in adjacent sites. This mechanism also shows the need for a $\mathrm{CO}_{2}$-rejecting buffered electrolyte. 


\subsection{CATALYSTS FOR METHANOL ELECTRO-OXIDATION}

In this section, the catalysts for electro-oxidation of methanol in acidic electrolytes and alkaline electrolytes are discussed.

\subsection{ACIDIC ELECTROLYTES}

For direct methanol oxidation in cells with acidic electrolytes, Pt catalysts are needed to achieve significant activity on the fuel electrode. The problems encountered with these catalysts are 1) the cost of the electrodes and 2) the poor stability of the catalysts. The initial activity of the Pt catalyst is high; however, these currents decay by as much as a factor of $10^{5}$ in the first five minutes of operation (McNicol 1984).

The rate of the methanol oxidation reaction is improved with electrocatalysts that adsorb water at potentials similar to the operating potential of the methanol oxidation reaction. Bimetallic catalysts of Pt, where the second metal adsorbs water at a lower potential than Pt (Watanabe and Motoo 1975), are more active. The interactions between the catalyst and its support also affect the rate of the reaction.

The effects of a binary Pt second metal catalyst on methanol electrooxidation were investigated. The bimetallic catalysts can be made by immersing Pt in a solution containing a salt of the second metal, or through under-potential deposition of the second metal. The highest activities were found for Pt-Sn (50 to $100 \times$ higher than those for a Pt catalyst), Pt-Ru $(25 \mathrm{x})$, Pt-Re $(30$ to $40 \mathrm{x}$ ) and Pt-Ti $(20$ to $25 \mathrm{x}$ ) catalysts (Janssen and Moolhuysen 1976a). These activities were found for optimal ad-atom coverage, in $1 \mathrm{M} \mathrm{CH}_{3} \mathrm{OH} / 0.5 \mathrm{M} \mathrm{H}_{2} \mathrm{SO}_{4}$ solutions at room temperature, and at $500 \mathrm{mV}$ with respect to a reversible hydrogen electrode in the same solution.

Figure 4.1 compares the activities of Pt, Pt-Ti, Pt-Sn, and Pt-Ru catalysts for the direct oxidation of methanol at $400^{\circ} \mathrm{F}$ in $99.5 \mathrm{wt} \% \mathrm{H}_{3} \mathrm{PO}_{4}$ with a methanol vapor pressure of $0.65 \mathrm{~atm}$ (Landsman and Luczak 1981). The improvement in the activities between the bimetallic alloys and $\mathrm{Pt} / \mathrm{C}$ is even 


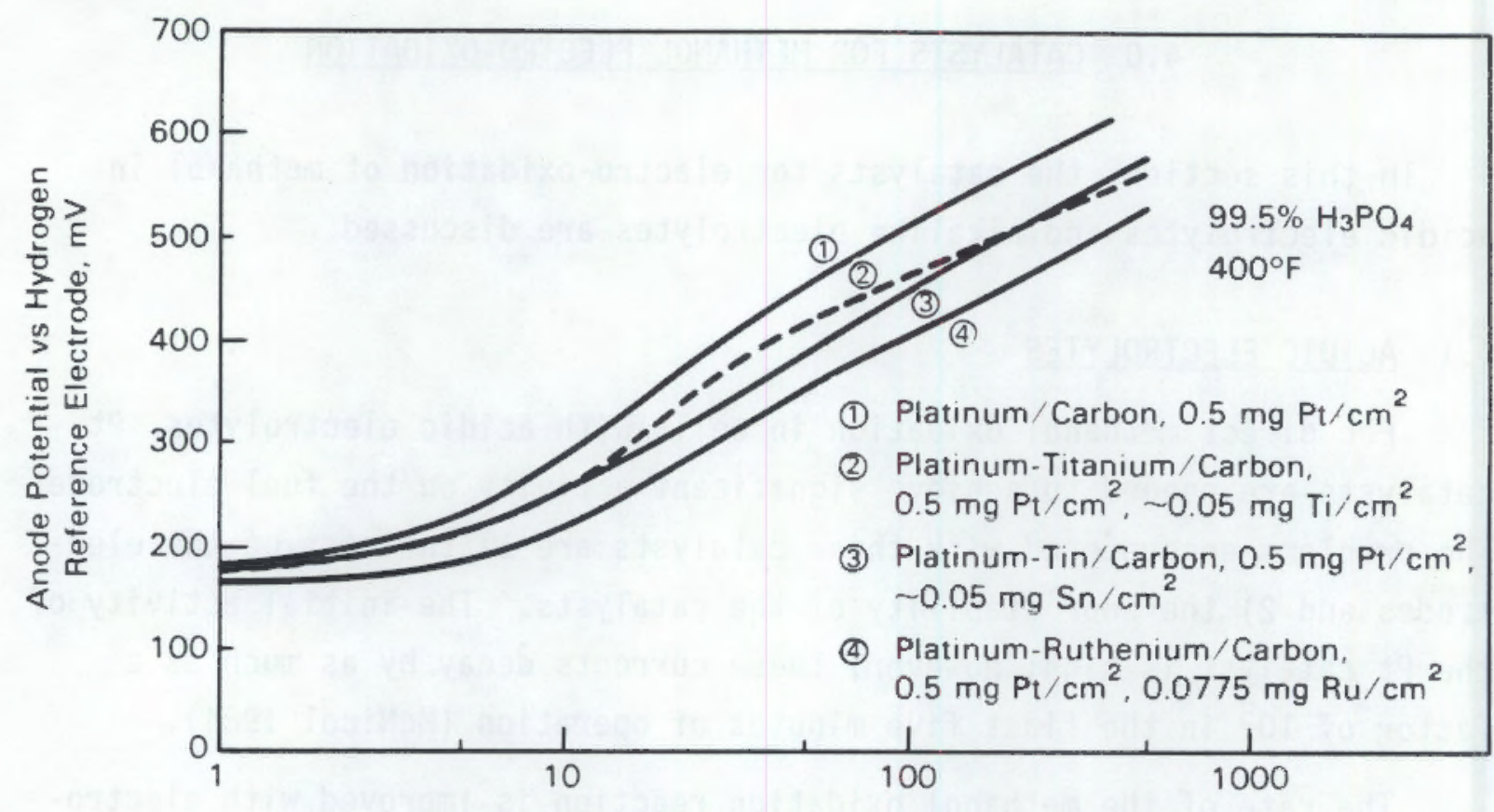

Normalized Current Density, i/L - mA/mg Pt

FIGURE 4.1. Comparison of Catalyst Performance for the Direct Oxidation of Methanol (Landsman and Luczak 1981)

greater than shown because the surface area of the alloys was about one-half the area of the Pt catalyst. The best activity per unit weight was found with Pt-Ru (Landsman and Luczak 1981).

The activities of the binary catalysts Pt-Sn, Pt-Pb, Pt-Re, and Pt-Ru were investigated using linear and cyclic voltammetry (Beden et al. 1981). The Pt-Sn, Pt-Pb and Pt-Re showed increased catalytic activity over Pt for specific concentration ranges of the binary salt used to prepare the catalyst and for specific potential ranges. Outside of those ranges, they behaved as catalytic poisons. The Pt-Ru consistently exhibited enhanced activity; however, it was not as high as with the Pt-Sn catalyst operating at low overpotentials.

The bimetallic catalysts show decreasing polarization with increasing temperature (Landsman and Luczak 1981). Figure 4.2 shows the effect of temperature on the $\mathrm{Pt}-\mathrm{Sn}$ catalyst in $99.5 \mathrm{wt} \% \mathrm{H}_{3} \mathrm{PO}_{4}$ with a methanol vapor pressure of $0.65 \mathrm{~atm}$. 


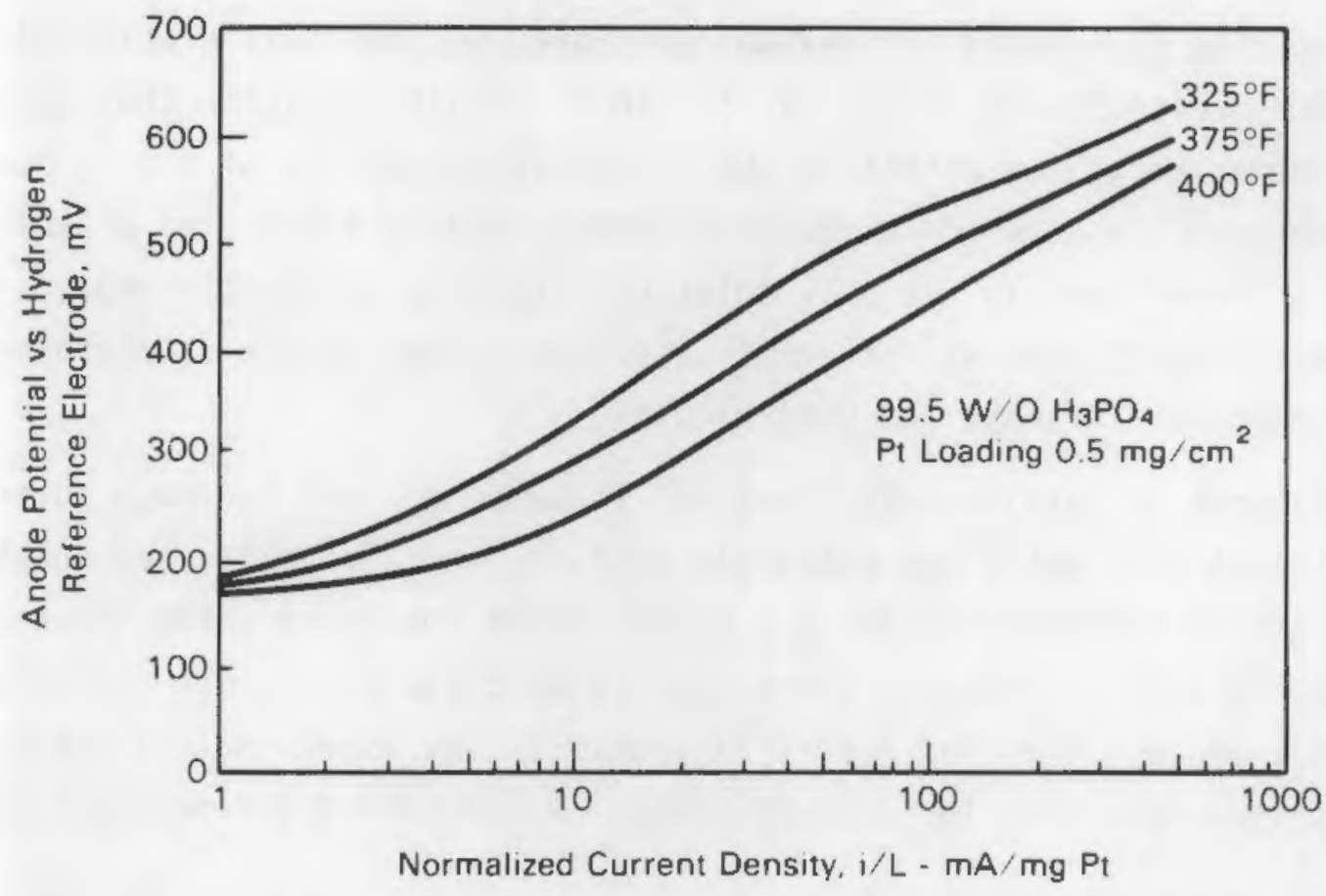

FIGURE 4.2. Direct Electrochemical Oxidation of Methanol on a Pt-Sn Catalyst (Landsman and Luczak 1981)

A rapid decay in the activity of a bimetallic catalyst occurs in the first few minutes of operation, although the decrease is not as severe as for Pt catalysts. After the initial drop in activity, the catalyst activity continues to decline steadily over thousands of hours. However, switching the current off for short periods allows the catalytic activity to return to pseudo steady-state activity (McNicol 1981, 1984). Shell Research has demonstrated very little loss of activity over thousands of hours of stop/start sequences (McNicol 1984).

Electro-oxidation of methanol on Pt bonded to cation exchange membranes (Nafion) and anion exchange membranes (Neosepta) was studied in perchloric acid solutions (Aramata and Ohnishi 1984). The polarization curves of methanol half-cell studies demonstrated that the activity depends on the membrane used and on the agent used to reduce the Pt onto the membrane $\left(\mathrm{NaBH}_{4}\right.$ or $\mathrm{N}_{2} \mathrm{H}_{4}$ ). The activity of a bulk platinized Pt electrode was measured for comparison, with the Pt electrode placed against an uncatalyzed Nafion membrane. After 20 hours of polarization, the ratios of the activities of the catalysts were 20:10:8:1 for the platinized Nafion/ $/ \mathrm{NaBH}_{4}$, the platinized Neosepta/ $\mathrm{NaBH}_{4}$ 
membrane, the platinized $\mathrm{Nafion} / \mathrm{N}_{2} \mathrm{H}_{4}$ membrane, and the bulk platinized $\mathrm{Pt}$ electrode, respectively (Figure 4.3). These results indicate that the matrix of the membrane has an effect on the catalytic properties of the Pt bonded to the membrane. Because ion-exchange membranes modify the states of the ions and water from those in the bulk solution, there is a possible redox coupling between $\mathrm{Pt}$ and $\mathrm{Pt}$ ions at different oxidation states on the catalyst bonded to the membrane (Aramata and Ohnishi 1984).

Research on catalysts that are not Pt-based has not had much success. One catalyst that exhibited catalytic activity was a tungsten and molybdenum mixed carbide electrocatalyst on a carbon fiber substrate (Kudo, Kawamura and Okamoto 1983). However, the potentiostatic current is one to two orders of magnitude less than for a pure Pt catalyst, and approximately three orders of magnitude less than for a Pt-Sn alloy. A molybdenum boride catalyst has
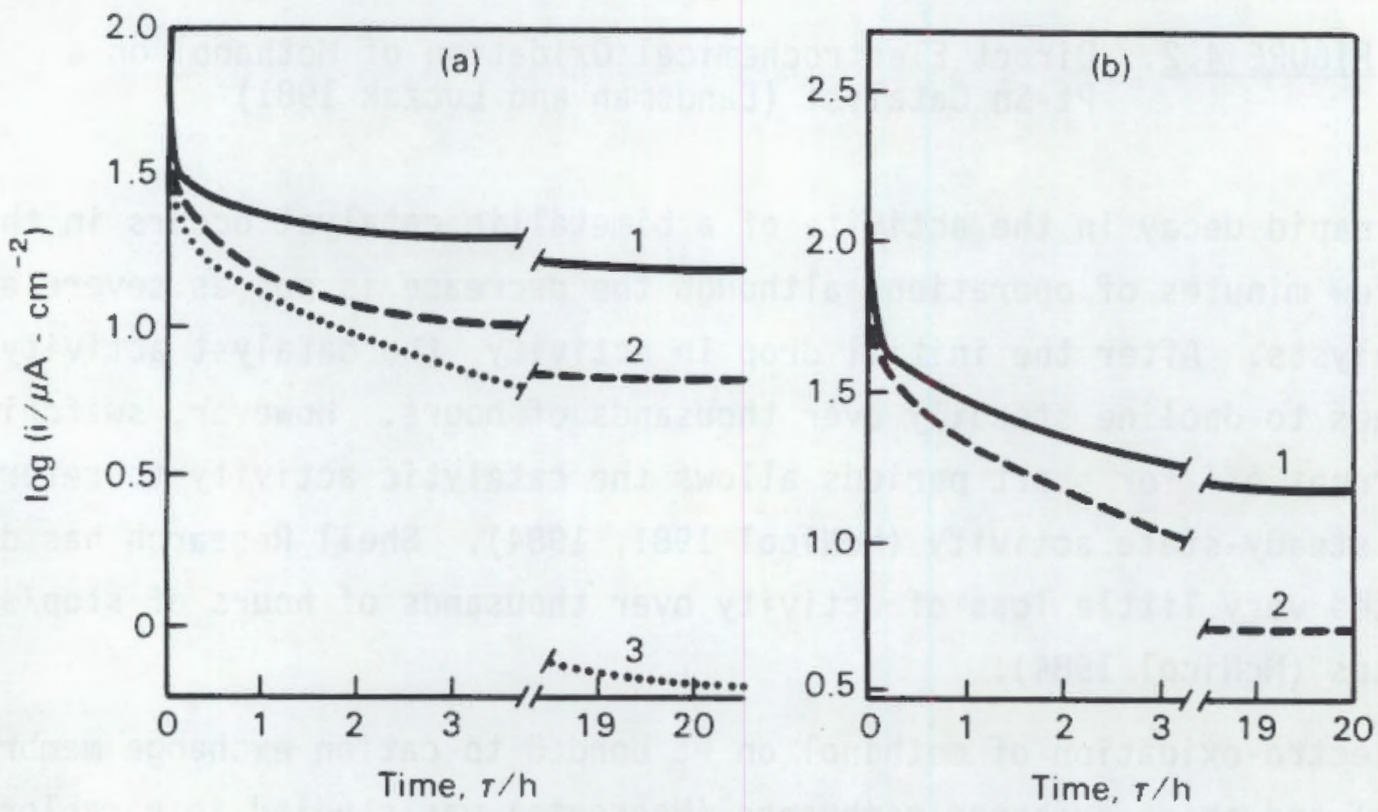

FIGURE 4.3. Current Versus Polarization Time Relations at $0.6 \mathrm{~V}$ on Pt-SPE and Bulk Pt in $1 \mathrm{M} \mathrm{CH}_{3} \mathrm{OH}+1 \mathrm{M} \mathrm{HClO}_{4}$ (Aramata and Ohnishi 1984)

(a) Curve 1: Pt-SPE (Nafion/ $\mathrm{NaBH}_{4}$ ) with roughness factor (r.f.) = 630; Curve 2: Pt-SPE (Neosepta $/ \mathrm{NaBH}_{4}$ ) with r.f. $=630$; platanized-platinum with r.f. $=200$.

(b) Curve 1: Pt-SPE (Nafion/ $\mathrm{NaBH}_{4}$ ) with r.f. = 37; Curve 2: Pt-SPE (Nafion $\left./ \mathrm{N}_{2} \mathrm{H}_{4}\right)$ with r.f. $=47$. 
been patented for methanol oxidation (Tetsuichi and Hidehito 1980), but no data are available to evaluate its activity.

Oxidation of methanol on agitated bed electrodes with nonmetallic catalysts was studied for activated charcoal powder, $\mathrm{Fe}_{2} \mathrm{O}_{3}, \mathrm{Al}_{2} \mathrm{O}_{3}$, Mo-O-S, W-O-S, and $\mathrm{Cu}_{2} \mathrm{~S}$ catalysts (Kurkowski and Phillips 1977). Platinum on charcoal agitated electrodes was also studied for comparison. On the basis of mass current density, Pt on charcoal was determined to be the best catalyst, although the Mo-0-S and $\mathrm{W}-0-\mathrm{S}$ systems provided promising results. On the basis of cost per improvement in current density, agitated beds of Mo-0-S, $\mathrm{W}-0-\mathrm{S}$, or $\mathrm{Cu}_{2} \mathrm{~S}$ could be considered as a feasible catalyst. However, the agitated bed electrodes were less effective than the Pt current collector electrode alone, even for the $\mathrm{Pt}$ on charcoal catalyst.

Based on this literature review, Pt-Ru was found to be the most active catalyst for methanol oxidation in an acidic medium. Also, a new method of preparing Pt-Ru cluster catalysts on carbon black (Watanabe, Uchida and Motoo 1986) has shown catalytic stability with continuous operation over four days as a methanol anode in zinc-electrowinning (Figure 4.4).

The activation conditions of Pt catalysts that are supported on carbonfiber paper were shown to have a critical effect on the catalytic activity (Attwood et a1. 1980). The effect on the fuel electrode performance is shown in Figure 4.5 for a Pt-Ru catalyst (McNicol 1981). Catalysts that were activated in hydrogen have lower activities than those activated in air, even though the Pt surface area is larger for catalysts treated with hydrogen. Attwood et al. (1980) suggested that the smaller Pt crystallites produced by hydrogen activation are less active, due to either the structure sensitivity of methanol oxidation or to weaker metal/carbon interactions. Further research determined that the activity of methanol oxidation increases with increasing Pt surface area until a maximum is reached at approximately $80 \mathrm{~m}^{2} / \mathrm{g}$, then decreases with further increases in the surface area (McNicol, Attwood and Short 1981) (Figure 4.6). The maximum activity occurred with a crystallite size that is much lower than that which normally enhances the 


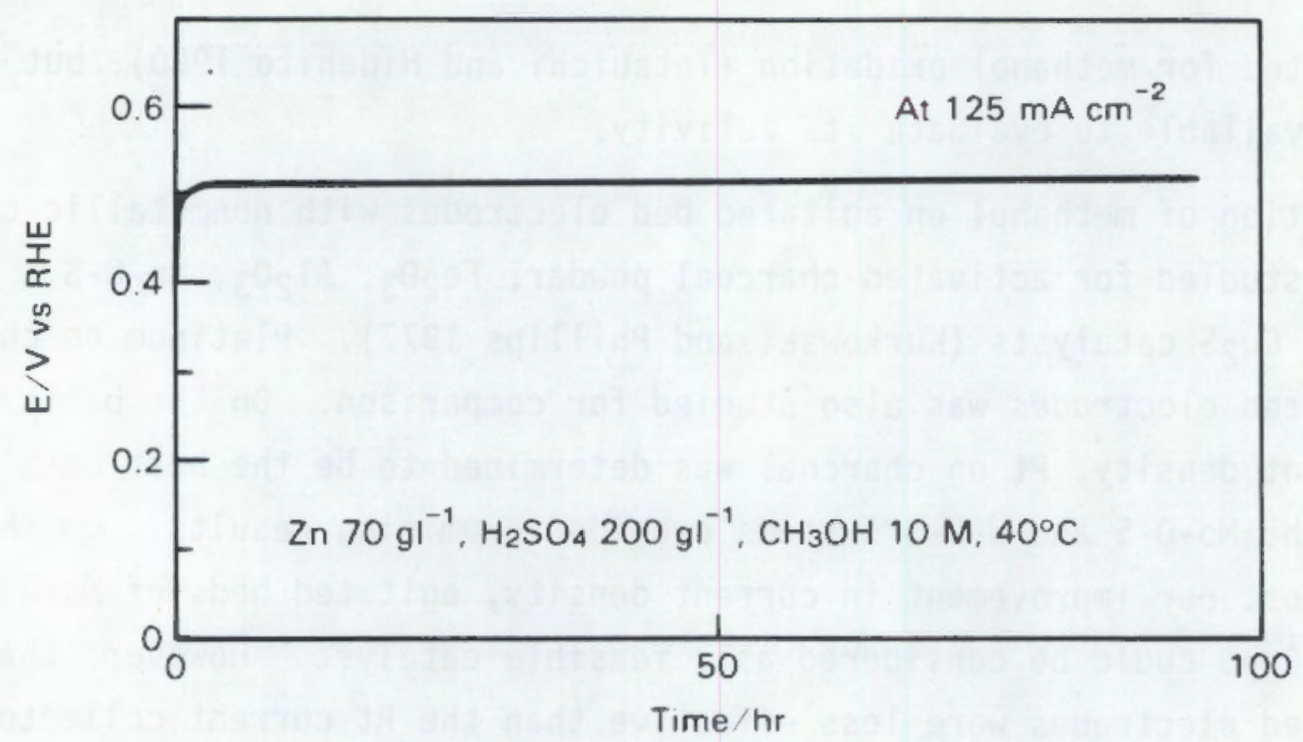

FIGURE 4.4. Potential Versus Time Relations of a Methanol Depolarized Anode of Pt-Ru Cluster Catalyst Supported on Carbon Black for Zinc Electrowinning (Watanabe, Uchida and Motoo 1986)

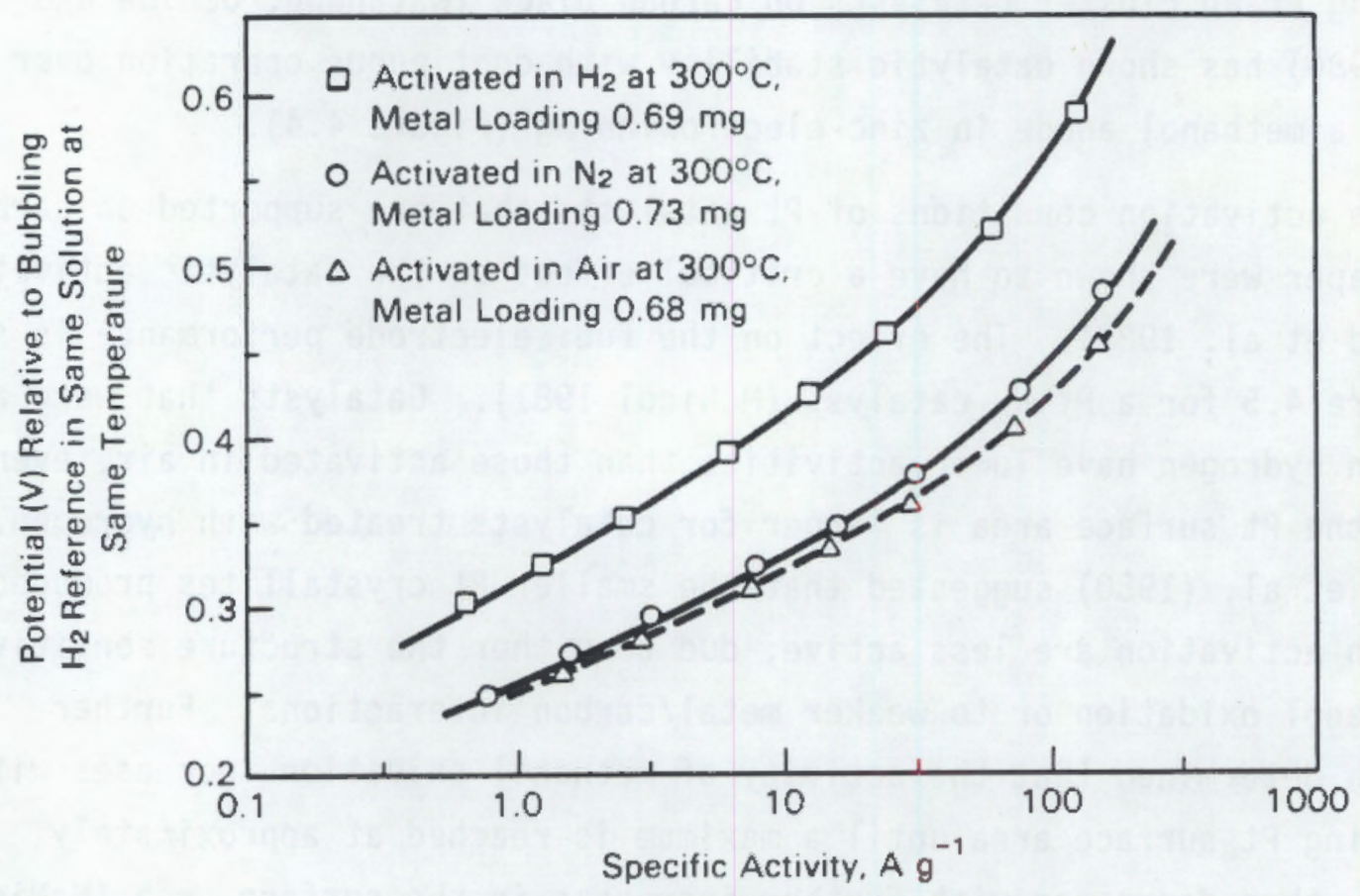

FIGURE 4.5. The Influence of Activation Conditions on the Performance of Pt-Ru Catalysts Supported on Pyrographite-Coated CarbonFiber Paper; $3 \mathrm{M} \mathrm{H}_{2} \mathrm{SO}_{4}, 1 \mathrm{M} \mathrm{CH} 3 \mathrm{OH}, 60^{\circ} \mathrm{C}$ (McNicol 1984) 


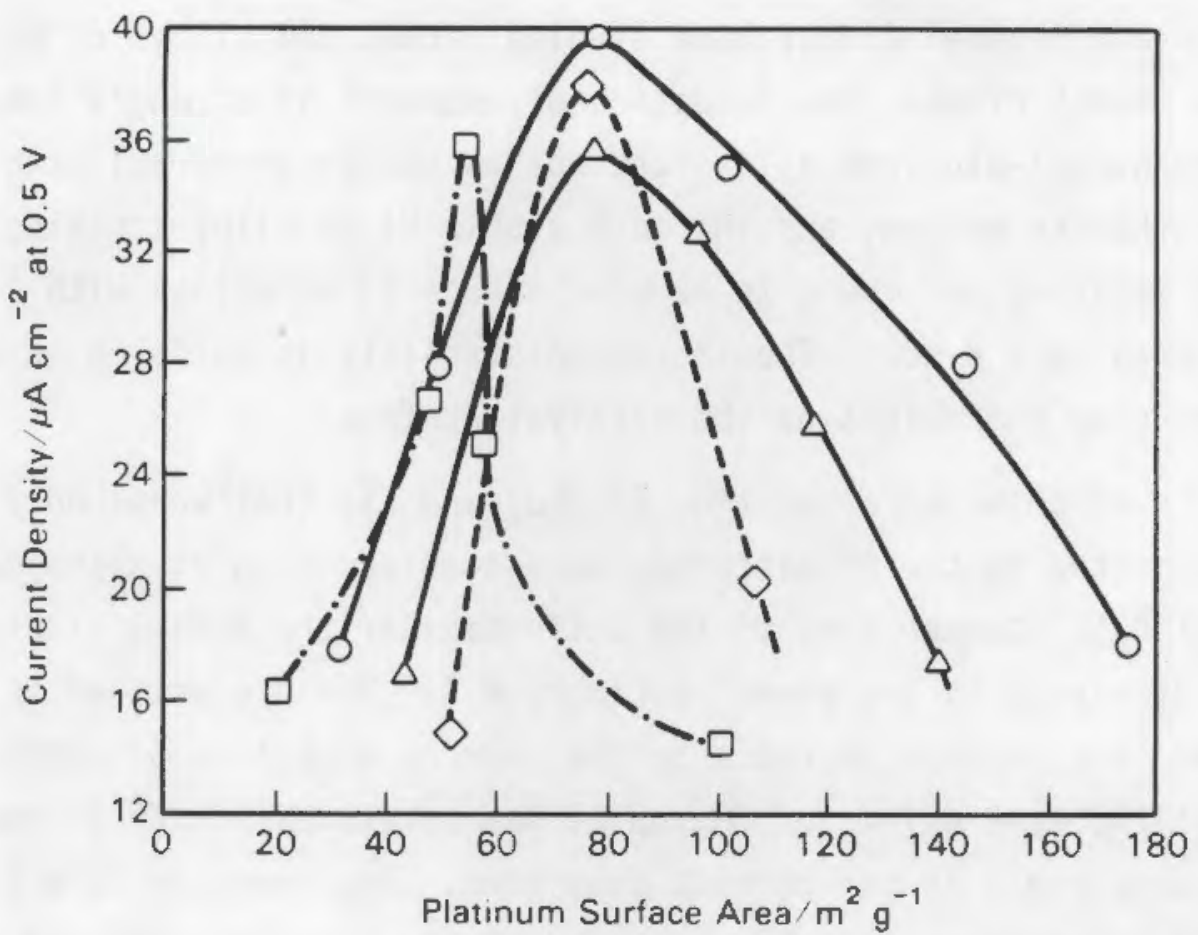

FIGURE 4.6. Relationship Between Intrinsic Activity and Pt Surface Area for Methanol Oxidation of Hydrogen-Activated Pt on Pyrographite-Coated Carbon-Fiber Paper (McNicol, Attwood and Short 1981)

Key: $\triangle O$ Catalyst Sintered by Electrochemical Cycling; Catalyst Sintered by Heating in Hydrogen; $\square$ Catalyst Sintered by Heating in Argon.

activity of reactions of this type. Thus, it is believed that the metalsupport interaction plays a role in determining activity (McNicol, Attwood and Short 1981).

\subsection{ALKALINE ELECTROLYTES}

Less research been published on electrocatalysts for methanol oxidation in an alkaline medium. Most of the alkaline methanol electro-oxidation literature discussed the discovery of an invariant electrolyte; Pt electrodes were used in these studies (Cairns and Bartosik 1964; Cairns and MacDonald 1964; Rupich, Galligan and Brummer 1984). 
Maximovich and Bronoel (1981) have studied nickel and alloys of nickel catalysts. On smooth nickel, the oxidation of methanol is strongly inhibited by oxides. The nickel-aluminum alloys are not as stable as nickel-zinc alloys in the alkaline medium, and the most stable $\mathrm{Ni}-\mathrm{Zn}$ alloy contains $50 \%$ $\mathrm{Zn}$. The $\mathrm{Ni}-\mathrm{Zn}$ catalyst was found to be more stable in solutions with $1 \mathrm{M}$ $\mathrm{KOH} / 1 \mathrm{M} \mathrm{CH}_{3} \mathrm{OH}$ than in $1 \mathrm{M} \mathrm{KOH}$. The increased stability is believed to be due to methanol reducing the oxides on the catalyst surface.

The effects of metal ad-atoms ( $\mathrm{Pb}, \mathrm{Bi}, \mathrm{Cd}$, and $\mathrm{Tl})$ that were underpotentially deposited on the Pt electrode were studied in an alkaline medium (Beden et al. 1982). Comparisons of the activities of the binary electrodes relative to a $\mathrm{Pt}$ electrode are shown in Figure 4.7. The presence of $\mathrm{Pb}$ and $\mathrm{Bi}$ ad-atoms led to a general increase in the current densities of methanol oxida-tion, but the main effect of $\mathrm{Cd}$ and $\mathrm{Tl}$ was a cathodic shift in the potential and a decrease in the current densities. The decrease in activity with the $\mathrm{Cd}$ and $\mathrm{Tl}$ ad-atoms is believed to be due to the fact that the potential of deposition of these metal atoms is positive to the potential range of methanol oxidation on Pt, causing the electro-active sites to be blocked by foreign metal atoms. The increased activity with the $\mathrm{Pb}$ and $\mathrm{Bi}$ is explained by the potential of deposition of these atoms being negative to the potential of methanol oxidation on pure Pt. This leads to an increase in the coverage of hydroxide ions on the Pt surface, enhancing the activity of the methanol oxidation reaction.

Ongoing DOE-sponsored work on buffered electrolytes has been investigating catalysts. Some of the binary Pt alloys have shown positive performance(a). That report is not presently available.

(a) Personal communication with M. W. Rupich, EIC Laboratories, Norwood, Massachusetts, June 1986. 

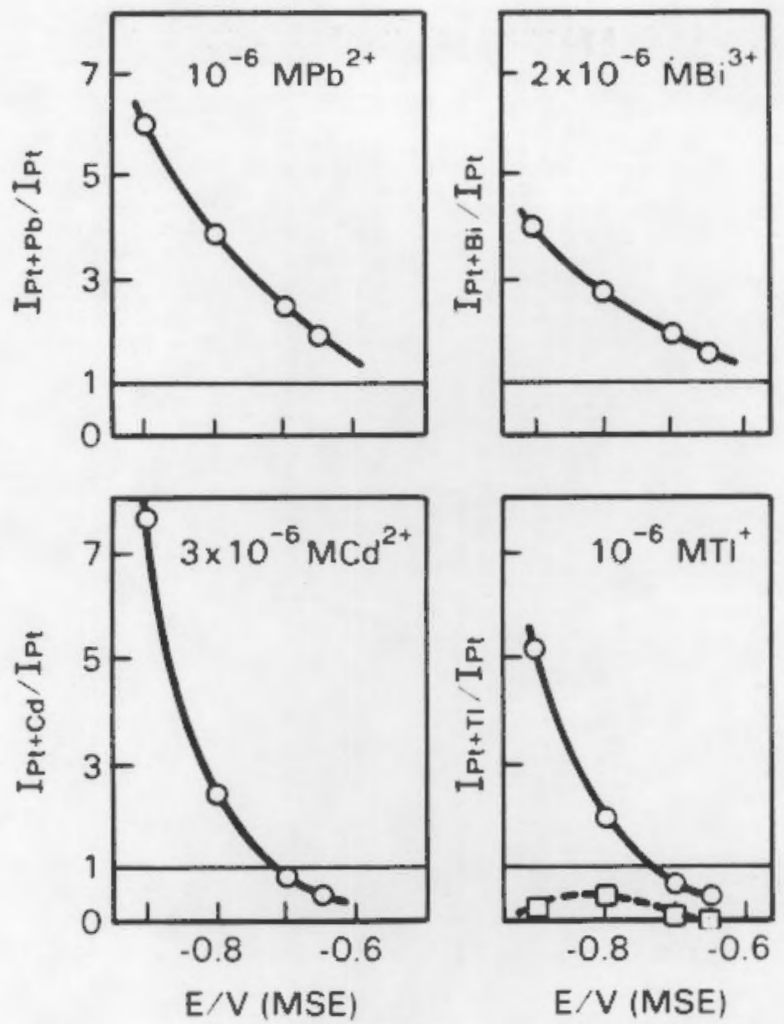

FIGURE 4.7. Ratios Between the Current of Methanol 0xidation on the Binary Electrode $\mathrm{Pt}+X$ (with $X=\mathrm{Pb}, \mathrm{Bi}, \mathrm{Cd}, \mathrm{Tl}$ ) and the Current on Pt, as a Function of the Electrode Potential in $0.1 \mathrm{M} \mathrm{NaOH}, 0.1 \mathrm{MaCH}_{3} \mathrm{OH}$, at $25^{\circ} \mathrm{C}, 50 \mathrm{mV} / \mathrm{s}$ (Beden et a7. 1982)

(a) $E_{C}=0.1 \mathrm{~V} / \mathrm{MSE}$, (except for $\mathrm{Tl}$ where $E_{C}=-1.0 \mathrm{~V} / \mathrm{MSE}$ ), $E_{a}=0.1 \mathrm{~V} / \mathrm{MSE}$. The dashed curve for 11 , with $E_{c}=-1.3$ V/MSE, shows a complete inhibition of the electrode reaction by bulk $\mathrm{Tl}$ atoms. 


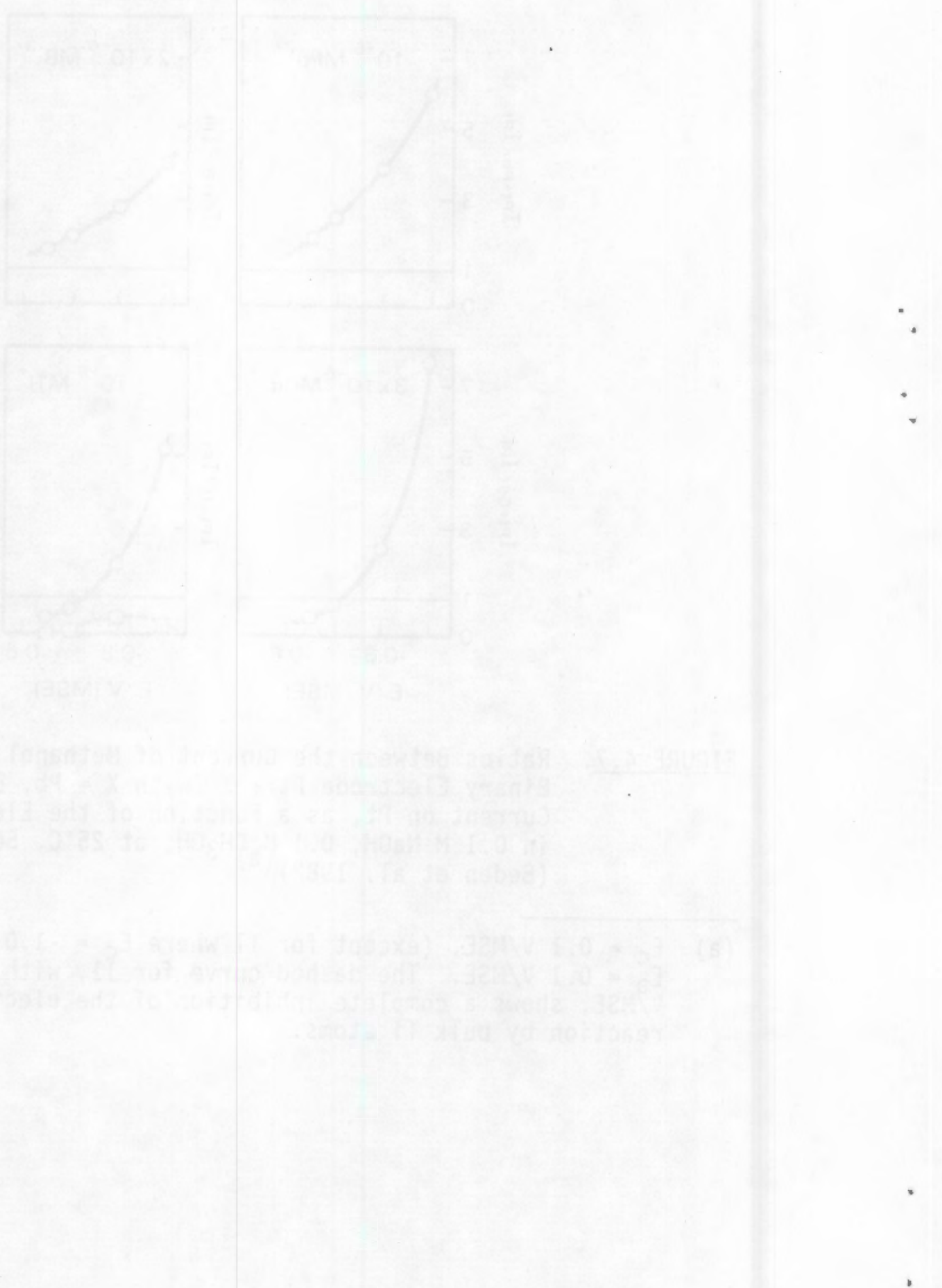




\subsection{PERFORMANCE TARGETS FOR METHANOL ELECTRO-OXIDATION CATALYSTS}

The balance of plant system required for a direct methanol fuel cell is simpler than the system required for the reformed methanol fuel cell. When methanol oxidation occurs directly at the anode, no fuel processor is required. This eliminates 1) the need for the high-temperature operation of the reformer, 2) the inefficiencies associated with the process, and 3) the need to develop a new reformer design and catalyst suitable for transient operation.

The battery required for startup and acceleration of a hybrid battery/ fuel cell system is smaller for the direct methanol fuel cell. The fuel is always dissolved in the electrolyte; consequently, the cell is maintained at the correct potential, even when the vehicle is at rest, leading to shorter startup times (Fedele and Donley 1980).

If the air electrode catalyst can withstand start/stop operation, the decrease in activity of the fuel electrode catalyst with time may not be a severe problem, because the $\mathrm{Pt}$-based anode catalysts are self-regenerative at open circuit conditions (McNicol 1984). Simple controls could be used to switch off the cells in rotation. The practicality of this method needs to be determined after taking into account the period of time required for this regeneration, which would determine the number of extra cells required.

Many engineering problems must be addressed before an actual full-size methanol-air fuel cell can be built and tested. One problem is the diffusion of methanol to the cathode where it reacts directly without producing any current. The diffusion can be prevented with an ion-exchange membrane, but the $i R$ losses across the membrane are high. High air-flow rates have been proposed as a solution; however, this results in lower conversion of oxygen at the air electrode (Landsman and Luczak 1981).

Another concern is the evaporative loss of methanol. This is more pronounced at higher-temperature operation, such as in cells with a phosphoric acid electrolyte. A method for recycling the steam may be needed, along with a method for removing the methanol vapors from the exhaust. 
For this study, the target efficiency of the direct methanol-air fuel cell system was assumed to equal the efficiency of the state-of-the-art reformed methanol/hydrogen-air fuel cell system.

The efficiency of direct methanol-air fuel cells was then compared with the efficiency of cells fueled by reformed methanol. This comparison assessed the improvements required for the direct methanol-air fuel cell to be competitive in performance with the reformed methanol fuel cell. The results of these comparisons are shown in Table 5.1, and the calculation method is given in the appendix.

The present methanol half-cell potential of $0.48 \mathrm{~V}$ versus hydrogen electrode in the same solution at $150 \mathrm{~mA} / \mathrm{cm}^{2}$ for a catalyst loading of approximately $0.5 / \mathrm{cm}^{2}$ needs to be improved by $0.41 \mathrm{~V}$ so that it would be approximately $0.07 \mathrm{~V}$ versus the hydrogen electrode in the same solution, in order for both systems to have equivalent efficiencies. The target performance of a methanol-air cell compared with the performance calculated from present technology is shown in Figure 5.1. The reversible voltages used in the calculations do not account for the temperature effects on the electromotive force (EMF).

These results seem reasonable; Landsman and Luczak (1981) have shown the anode polarization to be approximately $300 \mathrm{mV}$ higher for the direct oxidation of methanol than for the oxidation of hydrogen-rich gas, even with the best methanol electro-oxidation catalysts. This was believed to be the result of the inefficiency associated with the poisoning of the methanol catalyst and the migration of the methanol to the air electrode. 
TABLE 5.1. Results of Calculations Estimating the Polarization of the Anode of the Methanol-Air Cell for the Direct Methanol-Air System to pe as Efficient as the Reformed Methanol-Air System (a)

$\begin{array}{llccc}\text { Current Density }\left(\mathrm{mA} / \mathrm{cm}^{2}\right) & 50 & 100 & 150 \\ \text { Reformer Efficiency } & 0.93 & 0.93 & 0.93 \\ \text { Voltage of } \mathrm{H}_{2} \text {-Air Cell at I (b) } & 0.75 \mathrm{~V} & 0.71 \mathrm{~V} & 0.67 \mathrm{~V} \\ \text { Reversible Voltage of } \mathrm{H}_{2} \text {-Air Cel1 }(\mathrm{c}) & 1.30 \mathrm{~V} & 1.30 \mathrm{~V} & 1.30 \mathrm{~V} \\ \text { Voltage of Methanol-Air Cell at I (d) } & 0.38 \mathrm{~V} & 0.26 \mathrm{~V} & 0.18 \mathrm{~V} \\ \text { Reversible Voltage of Methanol-Air Ce11 }(\mathrm{e}) & 1.27 \mathrm{~V} & 1.27 \mathrm{~V} & 1.27 \mathrm{~V} \\ \text { Polarization of Methanol Electrode } & 0.41 \mathrm{~V} & 0.46 \mathrm{~V} & 0.48 \mathrm{~V} \\ \text { Improvement Desired in Polarization } & 0.29 \mathrm{~V} & 0.37 \mathrm{~V} & 0.41 \mathrm{~V}\end{array}$

(a) The reformed methanol/hydrogen-air data are for operation at $8.2 \mathrm{~atm}$ and at $1 \mathrm{~atm}$ for the methanol-air fuel cell. The temperature of both systems is $478^{\circ} \mathrm{K}$. The electrode area of both cells is assumed to be equal.

(b) $\mathrm{H}_{2}$-air cell voltages from United Technologies Power Systems (1982).

(c) Standard-state reversible cell voltages from Milazzo and Caroli (1977). Reversible voltage not corrected for $\mathrm{dE} / \mathrm{dT}$.

(d) Anode polarization data from Landsman and Luczak (1981), cathode polarization data from Kunz and Gruver (1975). Ohmic overpotential calculated as shown in Appendix, using data of Christner (1978), Kunz and Gruver (1975), and United Technologies Power Systems (1982).

(e) Standard-state reversible cell voltage calculated from Milazzo and Caroli (1977). Reversible voltage not corrected for $\mathrm{dE} / \mathrm{dT}$. 


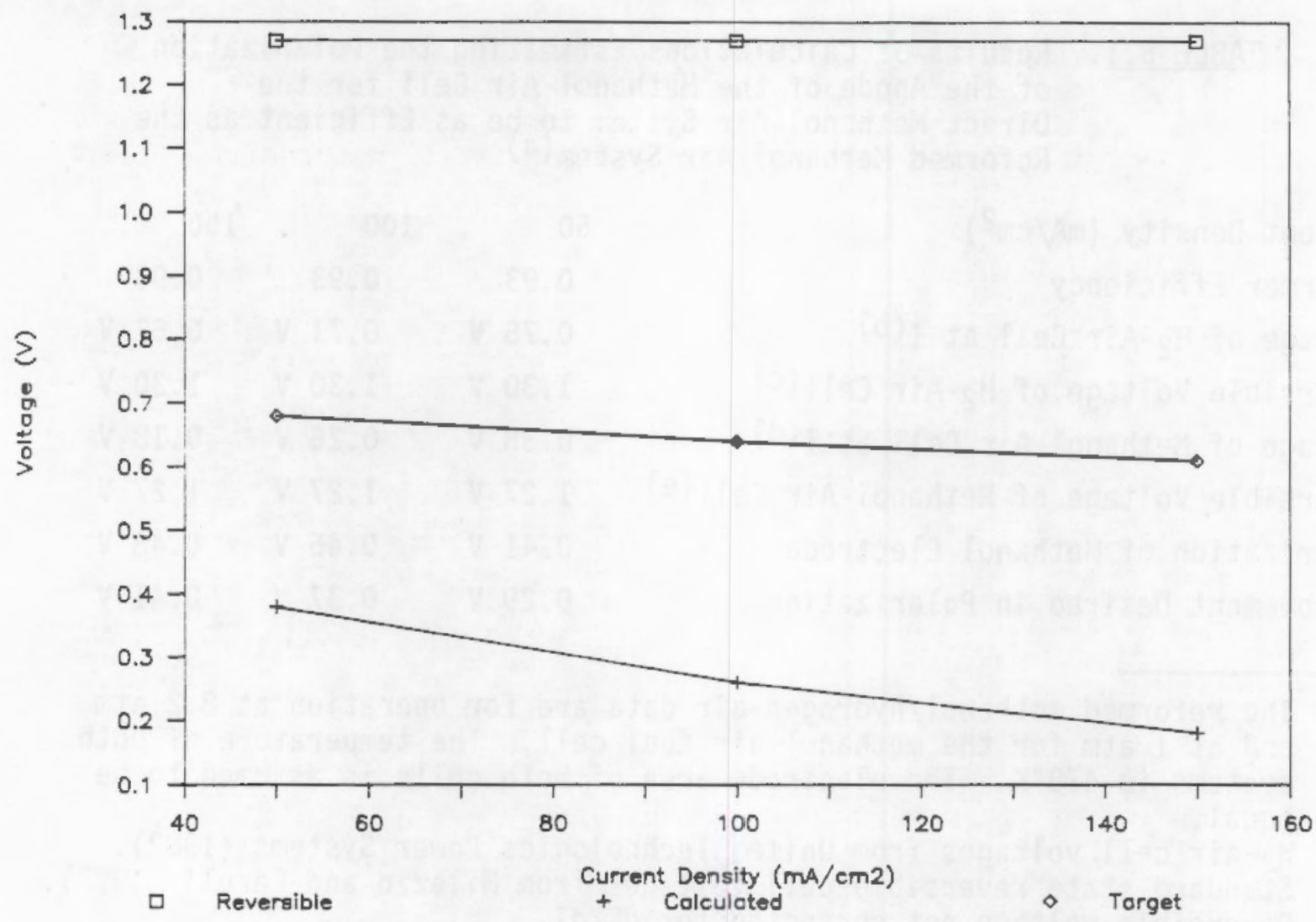

FIGURE 5.1. Comparison of the Calculated Methanol-Air Cell Voltage to the Target Cell Voltage in Phosphoric Acid Electrolyte at $200^{\circ} \mathrm{C}$ 


\subsection{CONCLUSIONS AND RECOMMENDATIONS}

The major obstacle in the development of the direct methanol fuel cell is the development of an active catalyst for the electro-oxidation of methanol. The need for simultaneous adsorption of water and methanol at similar potentials has been recognized since the early 1970s.(a) However, the nature of the adsorbed species and the precise mechanism have been disputed.(b) The activation condition of Pt catalysts dispersed on carbon fiber catalysts was also found to affect the activity of the oxidation reaction (Attwood et a1. 1980; McNicol, Attwood and Short 1981). The activity of the oxidation reaction was affected because of the structure sensitivity of the reaction and a weaker metal/carbon interaction with catalysts activated in hydrogen than with catalysts activated in air (McNicol, Attwood and Short 1981).

The goal of future research should be a better understanding of the mechanism of methanol electro-oxidation. Research should study the mechanisms as well as the structure sensitivity of adsorption and desorption of water on catalyst materials, and the adsorption and desorption of methanol on catalyst materials. This could be done by combining electrochemical techniques with in situ surface science methods (Melo 1984; Vielstich 1986).

The outcome of this research will create a predictive base that can be used to search for catalysts able to simultaneously adsorb methanol and water at similar potentials. In addition, the electronic interaction between the catalyst and the support affects the activity of the catalyst; therefore, these interactions must be characterized through spectroscopic measurements to select a support that promotes catalytic activity. Until a successful methanol oxidation catalyst is found, a development effort involving cell design and testing is not warranted.

(a) Bagotzky, Vassilev and Khazova (1977); Hampson, Willars and McNicol (1979); Sidheswaran and Lal (1972); Watanabe and Motoo (1975).

(b) Bagotzky, Vassilev and Khazova (1977); Breiter (1967a); Breiter (1967b); Hampson, Willars and McNicol (1979); Hughes and Miles (1983); McNicol (1978); Sidheswaran and Lal (1972). 



\subsection{REFERENCES}

Andrew, M. R., et al. 1977. "Electrolytes for Methanol Electro-oxidation Catalysts in Sulphuric Acid and Phosphoric Acid Electrolytes." J. Appl. Electrochem. $7: 153$.

Aramata, A., and R. Ohnishi. 1984. "Methanol Electro-oxidation on Platinum Directly Bonded to a Solid Polymer Electrolyte Membrane." J. Electroana]. Chem. 162:153.

Attwood, P. A., et a1. 1980. "Platinum on Carbon-Fibre Paper Catalysts for Methanol Electro-0xidation, Part I, Influence of Activation Conditions on Catalytic Activity." J. Chem. Soc. Faraday Trans. I. 76:2310.

Bagotzky, V. S., Y. B. Vassilev and 0. A. Khazova. 1977. "Generalized Scheme of Chemisorption, Electro-oxidation and Electroreduction of Simple Organic Compounds on Platinum Group Metals." J. Electroanal. Chem. 81:229.

Beden, B., et al. 1981. "Electrocatalytic 0xidation of Methanol on PlatinumBased Binary Electrodes." J. Electroana1. Chem. 127:75.

Beden, B., et a]. 1982. "Oxidation of Methanol on a Platinum Electrode in Alkaline Medium, Effect of Metal Ad-Atoms on the Electrocatalytic Activity." J. Electroanal. Chem. 142:171.

Breiter, M. W. 1967a. "A Study of Intermediate Adsorbed on PlatinizedPlatinum During the Steady-State Oxidation of Methanol, Formic Acid, and Formaldehyde." J. Electroanal. Chem. 14:407.

Breiter, M. W. 1967b. "Nature of Strongly Adsorbed Species Formed on Platinized PTatinum After the Addition of Methanol, Formic Acid, and Formaldehyde." J. Electroanal. Chem. 15:221.

Brookhaven National Laboratory. 1979. Fuel Cell Applied Research, Electrocatalys is and Materials. BNL 51038, Brookhaven National Laboratory, Upton, New York.

Cathro, K. J. 1967. "The Use of Platinum-Rhenium Catalysts for the Oxidation of Aqueous Methanol." Electrochemical Technology. 2:441.

Cairns, E. J., and D. C. Bartosik. 1964. "A Methanol Fuel Cell with an Invariant Electrolyte." J. Electrochem. Soc. 111:1205.

Cairns, E. J., and D. I. MacDonald. 1964. "Hydrocarbon Fuel Cells with Invariant Electrolytes." Electrochenical Technology. 2:65.

Christner, L. 1978. "Electrocatalysis of Acid Electrolyte Fuel Cell Reactions-Present Status and Recommended Research." In Proceedings of the Workshop on the Electrocatalysis of Fuel Cell Reactions, Volume 79-2. Electrochemical Society, Princeton, New Jersey. 
Fedele, J. B., and S. W. Donley. 1980. Fuel Cells for Vehicular Propulsion. Report ATR-80(5825)-3ND, The Aerospace Corporation, El Segundo, California.

Hampson, N. A., M. J. Willars and B. D. McNicol. 1979. "Study of the Methanol 0xidation Reaction on Platinum Using the Potential-Step Technique." J. Chem. Soc. Faraday Trans. I. 75:2535.

Huff, J. R., and H. S. Murray. 1982. Feasibility Evaluation of Fuel Cells for Selected Heavy Duty Transportation Systems. Los Alamos National Laboratory, Los Alamos, New Mexico.

Hughes, V. B., et al. 1977. "Electrolytes for Methanol-Air Fuel Cells II, the Electro-oxidation of Methanol in Trifluoromethane-sulphonic Acid Monohydrate and Aqueous Solutions of Trifluoromethane-sulphonic Acid." J. Appl. Electrochem. 7:161.

Hughes, V. B., and R. Miles. 1983. "A Cyclic Voltammetric Investigation of Adsorbed Residues Derived from Methanol on Platinum-Based Electrocatalysts." J. Electroanal. Chem. 145:87.

Janssen, M.M.P., and J. Moolhuysen. 1976a. "Binary Systems of Platinum and a Second Metal as 0xidation Catalysts for Methanol Fuel Cells." Electrochimica Acta, 21:869.

Janssen, M.M.P., and J. Moolhuysen. 1976b. "Platinum-Tin Catalysts for Methanol Fue] Cells Prepared by a Nove1 Immersion Technique, by Electrocodeposition and by Alloying." Electrochimica Acta. 21:861.

Kudo, T., G. Kawamura and H. Okamoto. 1983. "A New (W, Mo)C Electrocatalyst Synthesized by a Carbonyl Process: Its Activity in Relation to $\mathrm{H}_{2}$, HCHO, and $\mathrm{CH}_{3} \mathrm{OH}$ Electro-0xidation." J. Electrochem Soc. 130:1491.

Kunz, H. R., and G. A. Gruver. 1975. "The Catalytic Activity of Platinum Supported on Carbon for Electrochemical 0xygen Reduction in Phosphoric Acid." J. Electrochem. Soc. 122:1279.

Kurkowski, K.J.W., and C. R. Phillips. 1977. "0xidation of Methanol on Agitated Bed Electrodes Using Non-Metallic Electrocatalysts." Energy Conversion. 16:91.

Landsman, D. A., and F. J. Luczak. 1981. Investigation of the In-Situ Oxidation of Methanol in Fuel Cells. Report FCR-3463, United Technologies Power Systems, South Windsor, Connecticut.

Maximovitch, S., and G. Bronoel. 1981. "Oxidation of Methanol on Nicke1Zinc Catalysts." Electrochimica Acta. 26:1331.

McNicol, B. D. 1978. "The Electrocatalytic Aspects of Direct Dxidation of Methanol for Fuel Cell Applications." In Proceedings of the Workshop on the Electrocatalysis of Fuel Cell Reactions, volume 79-2. Electrochemical Society, Princeton, New Jersey. 
McNicol, B. D. 1981. "Electrocatalytic Problems Associated with the Development of Direct Methanol-Air Fuel Cells." Electroanal. Chem. 118:71.

McNicol, B. D. 1984. "Direct Methanol/Air Systems." In Studies in Electrical and Electronic Engineering 11. Power Sources for Electric Vehicles, eds. B. D. McNicol and D.A.J. Rand, Elsevier, New York.

McNicol, B. D., P. A. Attwood and R. T. Short. 1981. "Platinum on CarbonFibre Paper Catalysts for Methanol Electro-0xidation, Part II, Role of Platinum Surface Area in Determining Catalytic Activity for Methanol and Formic Acid Electro-Oxidation." J. Chem. Soc. Faraday Trans. 1. 77:2017.

McNicol, B. D., R. T. Short and A. G. Chapman. 1976. "Methanol Electrooxidation Catalysts, Platinum Promoted by Tin." J. Chem. Soc. Faraday Irans. I. $72: 2735$.

Me10, A. V. 1984. High Resolution Electron Energy Loss Spectroscopy Studies of Surface Reactions on Pt (111) (Hreels, Gas Adsorption), Ph.D. Thesis, Case Western Reserve University, Cleveland, Ohio.

Milazzo, G., and S. Caroli. 1977. Tables of Standard Electrode Potentials. Project of the IUPAC Electrochemistry Commission, John Wiley and Sons, New York.

National Materials Advisory Board, Commission of Engineering and Technical Systems, National Research Council. 1983. Fuel Cells Materials Technology in Vehicular Propulsion. Publication NMAB-411, National Academy Press, Washington, D.C.

Petkof, B. 1975. Mineral Facts and Problems. Bureau of Mines But7et in 667, United States Department of the Interior, Washington, D.C.

Rupich, M. W., D. A. Galligan and S. B. Brummer. 1984. Catalysis of Direct Methanol Electro-oxidation in Buffered_Electrolytes. EIC Laboratories, Inc., Waterbury, Connecticut.

Sidheswaran, P., and H. Lal. 1972. "Pre-exponential Factor and Mechanism of Anodic 0xidation of Chemisorbed Methanol and Formaldehyde on Platinum." J. Electroana1. Chem. 40:143.

Tetsuichi, K., and 0. Hidehito. U.S. Patent 42421, Hitachi Ltd., Japan, (1980).

United Technologies Power Systems. 1982. Assessment of Phosphoric Acid Fuel Cells for Vehicular Power Systems. FCR-4059, United Technologies Power Systems, South Windsor, Connecticut.

Vielstich, W. 1986. "New Results of the Electrocatalysis of Methanol 0xidation." Extended Abstracts. 86-1, Spring Meeting, Electrochemical Society, Princeton, New Jersey. 
Watanabe, M., and S. Motoo. 1975. "Electrocatalysis by Ad-Atoms, Part II, Enhancement of the Oxidation of Methanol on Platinum by Ruthenium Ad-

Atoms." J. Electroana7. Chem. 60:267.

Watanabe, M., M. Uchida and S. Motoo. 1986: "Pt-Ru Cluster Catalyst on Carbon Black and its Application to a BFE Type Methanol Depolarized Anode for Zinc Electrowinning." Extended Abstracts. 86-1, Spring Meeting, Electrochemical Society, Princeton, New Jersey. 


\section{APPENDIX}

METHOD USED TO CALCULATE DESIRED IMPROVEMENTS IN POLARIZATION OF THE METHANOL ELECTRODE 


\section{APPENDIX}

\section{METHOD USED TO CALCULATE DESIRED IMPROVEMENTS \\ IN POLARIZATION OF THE METHANOL ELECTRODE}

The efficiency of the direct methanol-air fuel cell was compared with the efficiency of the cell fueled by reformed methanol. The efficiency of the reformed methanol/hydrogen-air fuel cell is given by

$$
\eta=\eta \operatorname{ref}^{\eta_{F}} \eta_{V}
$$

where

$\eta=$ combined efficiency of methanol reformer and $\mathrm{H}_{2}$-air fuel cell

$\eta$ ref efficiency of reformer, fraction of methanol converted

$\eta_{\mathrm{F}}=$ faradaic efficiency of the hydrogen-air fuel cell

$\eta_{V}=$ voltaic efficiency of the hydrogen-air fuel cell.

The efficiency of the direct methanol-air fuel cell, $\eta^{\prime}$, is given by

$$
\eta^{\prime}=F_{V}^{\prime} \eta^{\prime}
$$

where

$$
\begin{aligned}
& \eta_{F}^{\prime}=\text { faradaic efficiency of the direct methanol-air fuel cell } \\
& \eta_{V}^{\prime}=\text { voltaic efficiency of the direct methanol-air fuel cell. } \\
& \text { The voltaic efficiency is defined as }
\end{aligned}
$$

$$
m=V(i) / V(i=0
$$

and the faradaic efficiency is given by

$$
\eta_{\mathrm{F}}=\frac{i}{n \mathrm{nN}_{\text {fuel }}}
$$


where

$$
\begin{aligned}
& i=\text { operating current, amps } \\
n & =\text { number of electrons transferred } \\
F & =\text { Faraday's constant, } 26.8 \mathrm{~A}-\mathrm{hr} / \mathrm{g} \text {-eq. } \\
\mathrm{N}_{\text {fuel }} & =\text { fuel flow rate, moles } / \mathrm{sec} .
\end{aligned}
$$

The efficiencies of the two fue 1 cell systems are related by

$$
\eta_{\text {ref }} \frac{V(i)}{V(i=0)} \frac{i}{\mathrm{nFN}_{\mathrm{H}_{2}}}=\frac{V^{\prime}\left(i^{\prime}\right)}{V^{\prime}\left(i^{\prime}=0\right)} \frac{i^{\prime}}{n^{\prime} \mathrm{FN}_{\mathrm{CH}_{3} \mathrm{OH}}}
$$

where the primes (') represent the direct methanol fuel ce11. Therefore, in order for the system directly fueled by methanol to have the same efficiency as the system fueled by reformed methanol, for operation at the same current, the methanol-air ce11 voltage must be given by

$$
V^{\prime}(i)=\eta_{\text {ref }} \frac{V(i)}{n \mathrm{FN}_{\mathrm{H}_{2}}} n^{\prime} \mathrm{FN} \mathrm{CH}_{3} \mathrm{OH} \frac{V^{\prime}(i=0)}{V(i=0)}
$$

If it is assumed that the flow rate of methanol entering the direct methanol fuel cell is the same as the flow rate of methanol entering the reformer of the system fueled by reformed methanol,

$$
\mathrm{N}_{\mathrm{H}_{2}}={ }^{3 \mathrm{~N}_{\mathrm{CH}} \mathrm{OH}}
$$

following the stoichiometry of the reaction taking place in the reformer,

$$
\mathrm{CH}_{3} \mathrm{OH}+\mathrm{H}_{2} \mathrm{O} \rightarrow 3 \mathrm{H}_{2}+\mathrm{CO}_{2}
$$

The electrochemical reaction taking place in the anode of the methanol-air fuel cell is

$$
\mathrm{CH}_{3} \mathrm{OH}+\mathrm{H}_{2} \mathrm{O} \rightarrow \mathrm{CO}_{2}+6 \mathrm{H}^{+}+6 \mathrm{e}
$$


so $n^{\prime}$ is 6 electrons per mole of methanol oxidized. The anodic reaction of the reformed methanol/hydrogen-air fuel cell is

$$
\mathrm{H}_{2}+2 \mathrm{e} \rightarrow 2 \mathrm{H}^{+}
$$

so $n$ is 2 electrons per mole of hydrogen oxidized.

Equation (A.6) can now be reduced to

$$
V^{\prime}(i)=\eta_{\text {ref }} V(i) \frac{V^{\prime}(i=0)}{V(i=0)}
$$

The reversible cell voltages, $V(i=0)$ and $V^{\prime}(i=0)$, were determined to be

$$
V(i=0)=E_{H_{2}}^{O}+E_{O_{2}}^{0}+\frac{R T}{2 F} \ln \frac{P_{H}{ }_{2}^{p_{2}}{ }^{l / 2}}{a_{H_{2} O}}
$$

for the cell fueled by reformed methanol, and

$$
V^{\prime}(i=0)=E^{0} \mathrm{CH}_{3} \mathrm{OH}^{+} \mathrm{E}_{\mathrm{O}_{2}}^{\mathrm{O}}+\frac{\mathrm{RT}}{6 \mathrm{~F}} \ln \frac{{ }^{\mathrm{a}} \mathrm{CH}_{3} \mathrm{OH} \mathrm{P}_{2}{ }^{3 / 2}}{\mathrm{P}_{\mathrm{CO}_{2}{ }{ }^{\mathrm{a}} \mathrm{H}_{2}{ }^{2}}}
$$

for the direct methanol oxidation cell.

The standard potentials are given by Milazzo and Caroli (1977) to be:

- $\mathrm{E}^{\mathrm{O}} \mathrm{H} 2=0.000 \mathrm{~V}$ in water at $25^{\circ} \mathrm{C}$ and atmospheric pressure

- $E^{\circ} \mathrm{O}_{2}=1.229 \mathrm{~V}$ in $2 \mathrm{~N} \mathrm{H}_{2} \mathrm{SO}_{4}$ at $25^{\circ} \mathrm{C}$ and atmospheric pressure

- ${ }^{\circ} \mathrm{C}_{\mathrm{H} 3 \mathrm{OH}}=0.054 \mathrm{~V}$ in water at $25^{\circ} \mathrm{C}$ and atmospheric pressure.

After $V^{\prime}(i)$ is calculated from the reformer efficiency and Equations (A.6), (A.12) and (A.13), the magnitude of improvements required in the anode polarization of the reformed methanol cell can be determined as follows.

This improvement, $v_{i m p}$, is given by

$$
V^{\prime}(i)=V+V \quad-i R+V
$$




$$
\mathrm{O}_{2} \quad \mathrm{CH}_{3} \mathrm{OH} \quad \text { imp }
$$

where

$$
\begin{aligned}
V_{02} & =\text { polarization of oxygen electrode for operation at } i \\
V_{\mathrm{CH} 30 \mathrm{H}} & =\text { polarization of methanol electrode for operation at } i \text {. }
\end{aligned}
$$

The ohmic overpotential, $i R$, is estimated from the cell voltage of a hydrogen-air cell with the same electrolyte concentration by

$$
i R=V(i)-V_{H_{2}}-V_{0}
$$

where $V_{\mathrm{H}_{2}}$ is the polarization of the hydrogen electrode at $i$. Combining equations (A.14) and (A.15) gives

$$
V_{i m p}=V^{\prime}(i)-V_{\mathrm{CH}_{3} \mathrm{OH}}-V_{\mathrm{O}_{2}} i \mathrm{R}
$$

Equation (A.16) should give a reasonable estimate of the magnitude of the decreases in polarization of the methanol electrode necessary for both systems to operate at the same efficiency, with the equal flow rates of methanol entering both systems, and to operate at the same current. 


\section{DISTRIBUTION}

No. of

Copies

A. R. Landgrebe

U.S. Department of Energy CE-32

1000 Independence Avenue, SW

Washington, DC 20585

J. E. Quinn

U.S. Department of Energy CE-32

Independence Avenue, SW

Washington, DC 20585

K. W. Klein

U.S. Department of Energy CE-32

1000 Independence Avenue, SW Washington, DC 20585

R. Eaton III

U.S. Department of Energy CE-32

1000 Independence Avenue, SW Washington, DC 20585

\section{P. G. Patil}

U.S. Department of Energy 1000 Independence Avenue, SW Washington, OC 20585

10 DOE Office of Scientific and Technical Information

E. J. Cairns

Lawrence Berkeley Laboratory University of $\mathrm{Cal}$ ifornia

Berkeley, CA 94720

R. B. Diegle

Sandia National Laboratories P.0. Box 5800

Albuquerque, NM 87185
No. of

Copies

J. R. Huff

Los Alamos National Laboratory

P.0. Box 1663

Los Alamos, NM 87545

K. Kinoshita

Lawrence Berkeley Laboratory

University of California

Berkeley, CA 94720

N. J. Magnani

Sandia National Laboratories

P.0. Box 5800

Albuquerque, NM 87185

J. McBreen

Brookhaven National Laboratory

Upton, NY 11973

F. R. McLarnon

Lawrence Berkeley Laboratory

University of California

Berkeley, CA 94720

W. E. O'Grady

Brookhaven National Laboratory

Upton, NY 11973

M. W. Rupich

EIC Laboratories, Inc.

111 Downey St.

Norwood, MA 02062

S. D. Fritts

Department of Chemical

Engineering

Case Western Reserve University

Cleveland, $\mathrm{OH} 44106$ 
No. of

Copies

R. A. Lemons

Los Alamos National Laboratory

P.0. Box 1663

Los Alamos, NM 87545

J. W. Hurwitch

Energetics, Inc.

9210 Route 108

Columbia, MD 21045

\section{FORE IGN}

B. D. McNicol

She11 Research Ltd.

Thornton Research Centre

P. 0. Box 1

Chester $\mathrm{CH}$ 3SH, ENGLAND

\section{ONSITE}

DOE Richland Operations office

J. J. Sutey

69 Pacific Northwest Laboratory

R. C. Adams

D. R. Brown

J. R. Divine

L. L. Fassbender

B. A. Garrett-Price

P. E. Hart

K. K. Humphreys

C. H. Imhoff

P. C. Rieke

J. T. A. Roberts

R. K. Sen (50)

S. L. Van Voorhees

T. A. Williams

Publishing Coordination (2)

Technical Report Files (5) 